\title{
Energy Minimization of Carbon Capture and Storage by means of a Novel Process Configuration
}

\author{
Hafiz Ali Muhammad ${ }^{\mathrm{a}, \mathrm{c}, \phi}$, Haider Sultan ${ }^{\mathrm{b}, \mathrm{c}, \phi}$, Beomjoon Lee ${ }^{\mathrm{a}}$, Muhammad Imran ${ }^{\mathrm{d}}$, Baek Il Hyun ${ }^{\mathrm{b}}$, \\ Young-Jin Baik ${ }^{\mathrm{a}, \mathrm{c}, *}$, and Sung Chan Nam ${ }^{\mathrm{b}, \mathrm{c}, *}$ \\ ${ }^{a}$ Thermal Energy Systems Laboratory, Korea Institute of Energy Research, Daejeon 305-343, South Korea \\ ${ }^{b}$ Greenhouse Gas Laboratory, Korea Institute of Energy Research, Daejeon 305-343, South Korea \\ c University of Science and Technology, Daejeon 305-350, South Korea \\ ${ }^{d}$ Mechanical Engineering and Design, School of Engineering and Applied Sciences, Aston University, B4 \\ 7ET, Birmingham, UK
}

(1)

\section{Abstract}

Carbon capture and storage is considered a key technology for decarbonizing the heat and power industries and achieving net zero emission targets. However, the significant energy requirements of the process as currently utilized hinders its widespread implementation. This work presents a novel process configuration by which the energy expenditures of carbon capture and storage can be minimized. This configuration is intended to enhance heat integration during the capture process through an innovative combination of three stripper modifications, namely lean vapor compression, a rich solvent split with vapor heat recovery and reboiler condensate heat recovery using a stripper inter-heater in a single flow-sheet. For carbon dioxide compression, a novel pressurization strategy involving carbon dioxide multi-stage compressors, a heat pump system and a supercritical carbon dioxide power cycle was designed and evaluated. The heat pump was used for carbon dioxide liquefaction while the supercritical carbon dioxide power cycle was employed to recover the intercooling heat. Through a comprehensive parametric investigation of the proposed configuration, the optimum value of the key operating parameters i.e., the split fraction, flash pressure, stripper inter-heater location, stripper inter-heater solvent flowrate, carbon dioxide liquefaction pressure and supercritical carbon dioxide cycle turbine pressure ratio were estimated. The performance of the proposed design at the optimized condition was quantified in terms of the reboiler heat duty, the carbon dioxide pressurization power and the equivalent work and compared to a baseline case post-combustion carbon capture and storage process. The proposed case reduced the reboiler heat duty from $3.36 \mathrm{GJ} / \mathrm{TonneCO}_{2}$ to $2.65 \mathrm{GJ} / \mathrm{TonnneCO}_{2}$ and the electric power required for carbon dioxide compression from $16,691 \mathrm{~kW}$ to $14,708 \mathrm{~kW}$. The results demonstrate that the new design can significantly

$\phi$ Both the authors contributed equally to this work.

* Corresponding Author: Young-Jin Baik (twinjin@kier.re.kr) and Sung Chan Nam (scnam@kier.re.kr) 
31 reduce the reboiler duty, compression power and equivalent work by $21.1 \%, 11.88 \%$, and $15.8 \%$, 32 respectively.

33

34 Keywords: Post-combustion carbon dioxide capture, Novel capture process configuration, Hybrid carbon

35 dioxide pressurization system, Supercritical carbon dioxide power cycle

\section{Nomenclature}

$37 \quad \mathrm{a}_{\mathrm{i}}$

$38 a^{g, l}$

$39 \mathrm{BC}$

$40 \mathrm{CCS}$

$41 \quad \mathrm{C}_{\mathrm{i}}$

$42 \quad \mathrm{C}_{\mathrm{P}}$

$43 \mathrm{dT}$

44 E

45 ENRTL

46 GA

$47 \mathrm{~h}$

$48 \quad \mathrm{H}$

$49 \mathrm{k}$

$50 \quad \mathrm{~K}$

$51 \mathrm{~m}$

$52 \mathrm{M}$

53 MEA

$54 \mathrm{n}$

$55 \mathrm{~N}$

56 ORC

$57 \quad \mathrm{P}$

58 PP

59 Q

$60 \mathrm{r}$

$61 \mathrm{R}$

$62 \mathrm{SH}$

$63 \mathrm{~s}$

$64 \mathrm{~T}$

65 HP

66 W

$67 \mathrm{X}$

68 State $1 \mathrm{CO}_{2}-12 \mathrm{CO}_{2}$

69 State 1Refr-4Refr
Stoichiometric coefficient of component $i$ in reaction equation.

Area of the gas-liquid interface

Conventional multistage compression established as the baseline case

Carbon capture and storage

Concentration of the $\mathrm{i}^{\text {th }}$ component

Specific heat capacity at constant pressure (J/kg.K)

Temperature difference

Activation energy $(\mathrm{Cal} / \mathrm{mol})$

Electrolyte non-random two-liquid

Genetic algorithm

Enthalpy $(\mathrm{J} / \mathrm{kg})$

Henry Constant

Pre-exponential factor

Overall mass transfer coefficient

Mass flow rate $(\mathrm{kg} / \mathrm{s})$

Rate of mass transfer

Monoethanolamine

Exponent of Temperature, which is zero

Number of components in the reaction

Organic Rankine Cycle

Pressure $(\mathrm{kPa})$

Pinch point in the heat transfer process

Rate of heat transfer (W)

Reaction rate.

Universal Gas Constant

Refrigerants' degree of superheat at the HP's compressor inlet (K)

Entropy (J/kg.K)

Temperature $(\mathrm{K})$

Heat pump

Power (W)

Quality

$\mathrm{CO}_{2}$ states

Refrigerant R290 states 


\section{Greek Symbols}

\begin{tabular}{|c|c|c|}
\hline 72 & $\phi$ & Percentage of savings in equivalent work \\
\hline 73 & $\eta$ & Isentropic efficiency of compressors and pumps \\
\hline 74 & $\gamma$ & Activity coefficient in liquid phase \\
\hline 75 & & \\
\hline 76 & Subscripts & \\
\hline 77 & $\mathrm{BC}$ & Conventional multistage compression established as the baseline case \\
\hline 78 & $\mathrm{C}$ & Cooling temperature \\
\hline 79 & Comp & Compressors \\
\hline 80 & Comp2 & $\mathrm{CO}_{2}$ compressor at the end of CCS chain \\
\hline 81 & $\mathrm{CW}$ & Cooling water \\
\hline 82 & $\mathrm{Eq}$ & Equivalent work \\
\hline 83 & Eva & Evaporator \\
\hline 84 & FG & Flue gas \\
\hline 85 & In & Incoming $\mathrm{CO}_{2}$ \\
\hline 86 & is & Isentropic \\
\hline 87 & o & Ambient conditions \\
\hline 88 & Out & Conditioned $\mathrm{CO}_{2}$ at the outlet \\
\hline 89 & ORC & Organic Rankine Cycle \\
\hline 90 & $\mathrm{PC}$ & Proposed design \\
\hline 91 & $\mathrm{R}$ & Ratio \\
\hline 92 & Refr & Refrigerant or HP working fluid \\
\hline 93 & $\mathrm{SC}$ & Subcooling \\
\hline 94 & $\mathrm{sCO}_{2}$ & Supercritical $\mathrm{CO}_{2}$ \\
\hline 95 & State $1 \mathrm{CO}_{2}-12 \mathrm{CO}_{2}$ & $\mathrm{CO}_{2}$ states \\
\hline 96 & State 1Refr-4Refr & Refrigerant R290 states \\
\hline 97 & Turb & Turbine \\
\hline
\end{tabular}

\section{Introduction}

Carbon capture and storage (CCS) is a key technological measure for reducing the emission of greenhouse gases (GHG) from stationary emission sources such as thermal power plants and ensuring a

103 sustainable and reliable global energy supply. CCS has the potential to significantly reduce carbon dioxide $104\left(\mathrm{CO}_{2}\right)$ emissions and mitigate climate change [1] and is, therefore, regarded as one of the most important 105 research frontiers for the development of a sustainable future [2]. Different technologies, including oxy106 fuel combustion, pre-combustion and post-combustion [3], as well as different materials that are capable of 107 selective sorption of $\mathrm{CO}_{2}$ (chemical or physical) [4] are available for $\mathrm{CO}_{2}$ sequestration. 
retrofitted into existing facilities [5]. The carbon capture step is followed by $\mathrm{CO}_{2}$ transportation to the storage site, as shown in Fig. 1. Both of the major steps involved in the CCS process $-\mathrm{CO}_{2}$ capture and transportation to a storage site - are energy-intensive processes and can produce up to a $14 \%$ reduction in net plant efficiency. This significantly high energy penalty hinders the implementation of CCS into power plants [6].

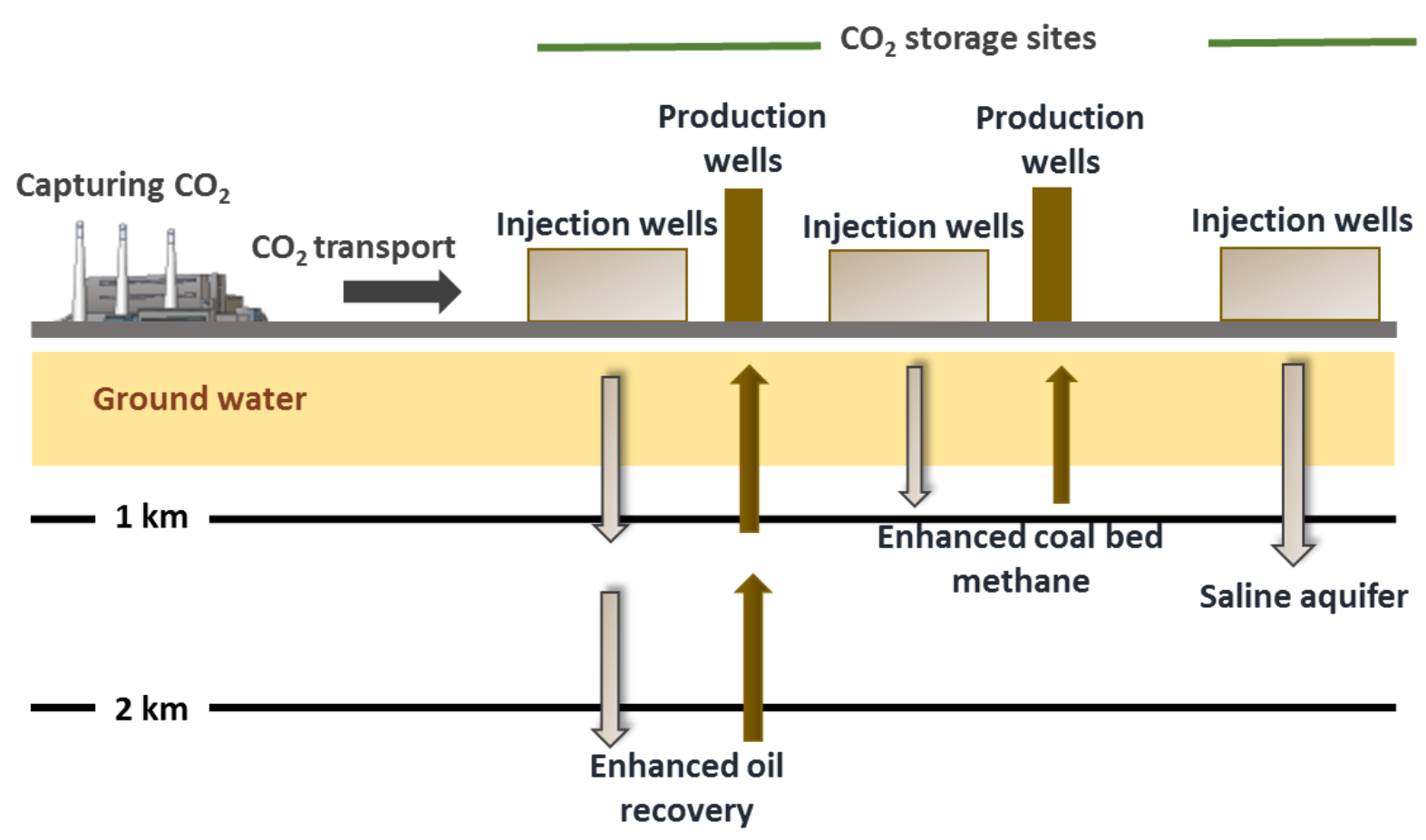

Fig. 1. Carbon capture and storage process.

In the amine absorption process, $\mathrm{CO}_{2}$ is absorbed at $40-60{ }^{\circ} \mathrm{C}$ in an absorber column that makes use of an aqueous amine solvent. This $\mathrm{CO}_{2}$-rich solvent is then thermally treated at $110-130{ }^{\circ} \mathrm{C}$ in a stripper column to produce pure $\mathrm{CO}_{2}$. The thermal treatment of the $\mathrm{CO}_{2}$-rich solvent requires a large amount of energy and accounts for approximately $70 \%$ of the total process cost [7]. Some researchers have focused on integrating CCS with renewable heat sources such as solar energy in order to provide the energy required for the thermal treatment of the solvent. However, this option remains economically unfeasible, as a large solar field is required to meet the high energy needs of solvent thermal treatment [8]. Therefore, various research activities are aimed at curtailing the energy expenditure of the CCS process by either improving the solvent for the absorption process [9] or the process configuration [10]. Improvement in the process configuration is easier and more effective, because it can be achieved with minimal retrofitting of any existing facility. 
Different process configurations such as absorber inter-cooling [10], stripper inter-heating [11], rich solvent splitting [12], stripper overhead compression [13], lean vapor compression (LVC) [14], rich vapor compression [14] and many other process modifications have been reported to reduce the energy penalty of the process. Dmartiz et al. [15] compared the energy consumption of various amine absorption process configurations and concluded that improvement to the configuration has substantial potential to improve the energetic efficiency of the process. Furthermore, the combination of different process configurations has more potential to reduce the energy consumption of the process. A combination of absorber inter-cooling, advanced rich solvent splitting and stripper inter-heating was simulated using ASPEN PLUS ${ }^{\mathrm{TM}}$ and resulted in an $18 \%$ reduction in reboiler duty [16]. Haider et al. [17] also examined the combination of capture process modifications and achieved $14 \%$ reduction in the reboiler duty.

The complete CCS process entails transporting sequestered $\mathrm{CO}_{2}$ from the capturing facility to the permanent storage site. Pipelines are considered a reliable and efficient mean of $\mathrm{CO}_{2}$ transportation where the required $\mathrm{CO}_{2}$ pressure ranges are from 150-200 bar [18]. Therefore, in the first step of the storage process, the pressure of the $\mathrm{CO}_{2}$ is to be boosted from the captured pressure (1.2-3.5 bar) to the pipeline pressure. The $\mathrm{CO}_{2}$ pressurization can result in an energy penalty of as high as $12 \%$ of the loss of power plant efficiency [19]. Therefore, to curtail this significant energy expenditure, extensive past research has focused on improving the $\mathrm{CO}_{2}$ compression process. Witkowski et al. [20] investigated a range of compression chain strategies and concluded that the requisite compression power can be reduced by designing a compression chain that makes use of $\mathrm{CO}_{2}$ liquefaction and pumping. This technique involves compressing the incoming $\mathrm{CO}_{2}$ from the capture unit to some intermediated liquefaction pressure, after which it is liquefied and then pumped to the target pressure. The liquefaction of $\mathrm{CO}_{2}$ requires sub-zero condensing temperatures, which makes the use of ambient sink impractical. Therefore, some research activities sought to design refrigeration cycles for $\mathrm{CO}_{2}$ liquefaction [21]. Alabdulakarem et al. [22] designed a vapor compression cycle (VCC) for $\mathrm{CO}_{2}$ liquefaction and pumping and explored various refrigerants. They concluded that by complementing the multistage compression with an ammonia-based vapor compression cycle, the power consumption could be reduced by $5.1 \%$ compared to conventional multistage compression.

The efficiency of the $\mathrm{CO}_{2}$ compression process can also be improved by recovering compression heat to produce useful work. Romeo et al. [23] optimized the $\mathrm{CO}_{2}$ compression process by investigating the compression ratio and converting the compression heat of the $\mathrm{CO}_{2}$ to low-pressure steam in the plant. Meanwhile, Kurtulus et al. [24] integrated an Organic Rankine Cycle (ORC) with $\mathrm{CO}_{2}$ compressors and conducted a thermodynamic analysis of their system. Pei et al. [25] conducted a similar analysis and concluded that the coupling of an ORC to shockwave-based $\mathrm{CO}_{2}$ compression is more promising than 
simple intercooling compression. Farajollahi et al. [26] studied the impact of integrating an ORC into a $3250 \mathrm{MW}$ thermal power plant with post-combustion $\mathrm{CO}_{2}$ capture and found out that the efficiency of the plant increased from $31.26 \%$ to $33.4 \%$ through the application of ORC.

Recently, to reduce the energy expenditure of the CCS process, the integration of fossil-fueled plants with solar hybrid systems has also been aggressively researched. Xu et al. [27] investigated a novel, direct-fired, oxy combustion supercritical $\mathrm{CO}_{2}\left(\mathrm{sCO}_{2}\right)$ power plant integrated with a solar-driven coal gasification array. They found that the proposed design reduced coal consumption by $29.9 \%$ and achieved a net energy efficiency of $43.4 \%$ with near zero carbon emissions. Similarly, Ghorbani et al. [28] proposed a tri-generation system to produce liquefied natural gas (LNG) and liquefied $\mathrm{CO}_{2}$ using an adsorption refrigeration system, and desalinated water. Their analysis revealed that hybrid poly-generation systems can enhance the exergetic efficiency of the system up to $88.97 \%$. Although hybrid systems exhibit promising potential to decarbonize the industry for greenfield plants, they lack the capacity to be retrofitted with the existing facility. Therefore, this study sets out to design an advanced CCS process configuration that can be adapted to greenfield plant designs or retrofitted with existing plants to reduce the energy expenditure of the CCS process.

Previous studies demonstrate that extensive research activities have focused on improving the capture process configuration and investigating a liquefaction system design for $\mathrm{CO}_{2}$ pressurization [29]. However, the majority of these research efforts have addressed these problems separately; therefore, this study aims to remedy this gap by evaluating the entire process chain of $\mathrm{CO}_{2}$ capture and liquefaction. Recently, Aliyon et al. [30] examined the compete $\mathrm{CO}_{2}$ capture and liquefaction process; however, their study employed a conventional capture process configuration and ship-based $\mathrm{CO}_{2}$ transportation. The $\mathrm{CO}_{2}$ target pressure for their ship-based transportation was 19.7 bar and 26.5 bar, which makes the design of their $\mathrm{CO}_{2}$ pressurization system significantly differs from pipeline-based transportation.

The originality of this work includes incorporating the complete CCS process while proposing and optimizing a new design for capture, as well as the pressurization process. For the capture process, the combination of stripper modifications has shown improvement potential. Jin et al. [31] reported a $28 \%$ reduction in energy consumption by incorporating a combination of stripper modifications, which included an air stripper, flue gas membrane pre-separation, inter-cooler and rich solvent split. However, their study did not consider the auxiliary loads of the added equipment, while the installation of a membrane increases the complexity of the process. In this study, three stripper modifications, namely LVC; a rich solvent split with vapor heat recovery; and heat recovery from reboiler condensate using stripper inter-heater are incorporated into a single flowsheet and auxiliary loads are accounted for while calculating net energy 
consumption. For the pressurization process, Muhammad et al. [29] found that integrating liquefaction and pumping into the pressurization system can save the electric power, while Kurtulus et al. [24] demonstrated that the intercooling heat of $\mathrm{CO}_{2}$ compressors can be recovered to produce power. This study consolidated the effects of liquefaction and pumping and the recovery of intercooling heat by devising a hybrid $\mathrm{CO}_{2}$ pressurization scheme. The proposed pressurization scheme involves multi-stage compressors, a heat pump (HP) system for $\mathrm{CO}_{2}$ liquefaction and an $\mathrm{sCO}_{2}$ power cycle to recover the intercooling heat. Unlike previous studies that investigated ORC to recover the intercooling heat, this study employs an $\mathrm{sCO}_{2}$ cycle. The $\mathrm{sCO}_{2}$ cycle offers better efficiency compared to the ORC while harnessing low-to mid-temperature heat sources [32] and integrating the $\mathrm{sCO}_{2}$ cycle with the proposed $\mathrm{CO}_{2}$ pressurization scheme does not require any additional working fluid inventory. The capture process configurations were simulated and optimized using ASPEN PLUS ${ }^{\mathrm{TM}}$ V10.1 rigorous rate-based modeling, whereas the $\mathrm{sCO}_{2}$ cycle integrated pressurization scheme was modelled and optimized in the MATLAB environment. The energy expenditure of the proposed capture and pressurization configuration was then calculated at the optimized conditions. The resulting reduction in heat duty and electric power using the proposed design is converted to equivalent work $\left(\mathrm{W}_{\mathrm{Eq}}\right)$ for a fair comparison with the baseline case $(\mathrm{BC})$.

\section{Amine-based carbon dioxide capture process description and modelling}

The monoethanolamine (MEA) was used as an absorbent during the $\mathrm{CO}_{2}$ capture process. The liquid phase was modelled using Electrolyte Non-Random Two Liquid (ENRTL) property package while the vapor phase was modelled using the Redlich-Kwong (RK) equation of state. Absorber and stripper columns were simulated using rigorous rate-based models. FLEXIPAC 250Y was used as packing material in the absorber and stripper columns. Absorber and stripper specifications for the CCS process are presented in Table 1. The $\mathrm{CO}_{2}$ capture process was designed for $90 \%$ efficiency at a removal rate of 190 Tonne/hr. The $\mathrm{CO}_{2}$ capture process was designed for $300 \mathrm{MW}$ coal-based power plants with a designed capacity of 1.5 million tonnes of $\mathrm{CO}_{2}$ captured per annum. The flue gas composition was set in accordance with the guidelines provided by the Department of Energy (DOE) for the $\mathrm{CO}_{2}$ capture process. The flue gas molar composition and other specifications are provided in Table 2. These simulation bases were retained throughout the analysis. 
Table $1 . \mathrm{CO}_{2}$ capture process specifications

\begin{tabular}{|c|c|c|}
\hline \multicolumn{2}{|c|}{ Component } & Specification \\
\hline \multicolumn{2}{|c|}{ Plant type } & Coal-based, $300[\mathrm{MW}]$ \\
\hline \multirow{2}{*}{ Absorber } & Height & $24[\mathrm{~m}]$ \\
\cline { 2 - 3 } & Diameter & $13[\mathrm{~m}]$ \\
\hline \multirow{2}{*}{ Stripper } & Height & $11[\mathrm{~m}]$ \\
\cline { 2 - 3 } & Diameter & $8[\mathrm{~m}]$ \\
\hline \multicolumn{2}{|c|}{ Amine flowrate } & $2900[$ Tonne/hr] \\
\hline $\mathrm{CO}_{2}$ capture rate (mCO2) & $190[$ Tonne/hr] \\
\hline \multicolumn{2}{|c|}{$\mathrm{CO}_{2}$ capture efficiency } & $90 \%$ \\
\hline \multicolumn{2}{|c|}{$\mathrm{CO}_{2}$ product purity } & $99 \mathrm{wt} \%$ \\
\hline
\end{tabular}

Table 2. Flue gas specifications

\begin{tabular}{|c|c|}
\hline Component & Molar composition \\
\hline $\mathrm{CO}_{2}$ & $13[$ mole \%] \\
\hline $\mathrm{O}_{2}$ & $5[$ mole \%] \\
\hline $\mathrm{H}_{2} \mathrm{O}$ & $10[$ mole \%] \\
\hline $\mathrm{N}_{2}$ & $72[$ mole \%] \\
\hline Pressure $\left(\mathrm{P}_{\mathrm{FG}}\right)$ & $1.5[\mathrm{bar}]$ \\
\hline Temperature $\left(\mathrm{T}_{\mathrm{FG}}\right)$ & $40\left[{ }^{\circ} \mathrm{C}\right]$ \\
\hline Flowrate $\left(\mathrm{m}_{\mathrm{FG}}\right)$ & $300[\mathrm{~kg} / \mathrm{s}]$ \\
\hline
\end{tabular}

\subsection{Process chemistry}

The capture process, essentially a chemical process involving a variety of species and a series of reactions, was modelled using Aspen Plus ${ }^{\circledR}[33]$. A water, amine and $\mathrm{CO}_{2}$ mixture were thermodynamically modeled using the ENRTL property package in Aspen Plus ${ }^{\circledR}$ [33]. The chemical reactions taking place in

$$
r=k(T)^{n} \exp \left[\left(\frac{-E}{R}\right)\right] \prod_{i=1}^{N} C_{i}^{a_{i}}
$$


Table 3. Reaction kinetics

\begin{tabular}{|c|c|c|c|}
\hline Reactions & Type & $\begin{array}{c}\text { Rate constant } \\
\qquad(\mathrm{k})\end{array}$ & $\begin{array}{c}\text { Activation } \\
\text { energy (E) } \\
{[\mathrm{Cal} / \mathrm{mol}]}\end{array}$ \\
\hline $\mathrm{H}_{2} \mathrm{O}+\mathrm{MEAH}^{+} \leftrightarrow \mathrm{MEA}+\mathrm{H}_{3} \mathrm{O}^{+}$ & Equilibrium & - & - \\
\hline $2 \mathrm{H}_{2} \mathrm{O} \leftrightarrow \mathrm{H}_{3} \mathrm{O}^{+}+\mathrm{OH}^{-}$ & Equilibrium & - & - \\
\hline $\mathrm{HCO}_{3}^{-}+\mathrm{H}_{2} \mathrm{O} \leftrightarrow \mathrm{CO}_{3}^{2-}+\mathrm{H}_{3} \mathrm{O}^{+}$ & Equilibrium & - & - \\
\hline $\mathrm{CO}_{2}+\mathrm{OH}^{-} \leftrightarrow \mathrm{HCO}_{3}^{-}$ & Kinetic & $4.32 \mathrm{e}+13$ & 13249 \\
\hline $\mathrm{HCO}_{3}^{-} \leftrightarrow \mathrm{CO}_{2}+\mathrm{OH}^{-}$ & Kinetic & $2.38 \mathrm{e}+17$ & 29451 \\
\hline $\mathrm{MEA}+\mathrm{CO}_{2}+\mathrm{H}_{2} \mathrm{O} \leftrightarrow \mathrm{MEACOO}^{-}+\mathrm{H}_{3} \mathrm{O}^{+}$ & Kinetic & $9.77 e+10$ & 9855.8 \\
\hline $\mathrm{MEACOO}^{-}+\mathrm{H}_{3} \mathrm{O}^{+} \leftrightarrow \mathrm{MEA}+\mathrm{CO}_{2}+\mathrm{H}_{2} \mathrm{O}$ & Kinetic & $3.23 e+19$ & 156554 \\
\hline
\end{tabular}

234

235

236

237

238

239

240

241

242

243

244

245

246

247

248

249

250

\subsection{Mass transfer in the carbon dioxide capture process}

The mass transfer rate in the gas-liquid interface is expressed by Eq. (2) [34], below. The overall mass transfer coefficient is calculated by Eq. (3) [34].

$$
\begin{aligned}
& M_{i}=a^{g, l} N_{i}=a^{g, l} K_{t o t, i}\left(P_{i}^{e q}-P_{i}\right)=a^{g, l} K_{t o t, i}\left(H_{E, i} \gamma_{i} c_{i}-P_{i}\right) \\
& \frac{1}{K_{\text {tot }, i}}=\frac{R T}{k_{i}^{g}}+\frac{H_{E, i}}{k_{i}^{l}}
\end{aligned}
$$

The individual coefficients of mass transfer for species " $\mathrm{i}$ " are represented by $k_{i}^{g}$ and $k_{i}^{l}$ in the gas and liquid phases, respectively. Henry's Constant for $\mathrm{CO}_{2}$ solubility in water is obtained by regressing Vapor Liquid Equilibrium data [35], while that for $\mathrm{CO}_{2}$ in MEA is obtained from Wang et al. [36]. The non-random two-liquid (NRTL) model's interaction parameters between MEA \& water are obtained from Austgen et al. [37]. The NRTL interaction parameters are set to zero between $\mathrm{CO}_{2}$ and water. The interfacial area $\left(a^{g, l}\right)$ and mass transfer coefficient in the liquid $\left(k_{i}^{l}\right)$ and gas $\left(k_{i}^{g}\right)$ phases are derived from Bravo et al. [38].

\subsubsection{Baseline case: The carbon dioxide capture process}

The conventional $\mathrm{CO}_{2}$ capture process is shown in Fig. 2. The $30 \mathrm{wt} \%$ MEA solvent enters from the top of the absorber column and absorbs $\mathrm{CO}_{2}$ from the flue gas emanating from the bottom of the absorber. After the absorption of $\mathrm{CO}_{2}$, clean gas exits from the top of the absorber. The $\mathrm{CO}_{2}$-rich solution from the 
251 bottom of the absorber is then pumped to an economizer before regenerating the $\mathrm{CO}_{2}$-rich solvent in the 252 stripper column. In the stripper column, $\mathrm{CO}_{2}$ is stripped from the $\mathrm{CO}_{2}$-rich solvent by heating it in a reboiler. 253 The stripped $\mathrm{CO}_{2}$, along with the evaporated water vapors, exit from the top of the stripper column and 254 move to the condenser, where they are cooled. The cooled 2-phase mixture is separated in a flash column 255 that sends the condensed water back to the stripper as reflux and the separated $\mathrm{CO}_{2}$ to the compression unit 256 to increase the pressure up to 150 bar for transportation and storage. The lean solvent from the stripper 257 bottom exchanges heat in the economizer with $\mathrm{CO}_{2}$-rich solvent and is cooled to $40{ }^{\circ} \mathrm{C}$ before feeding back 258 into the absorber.

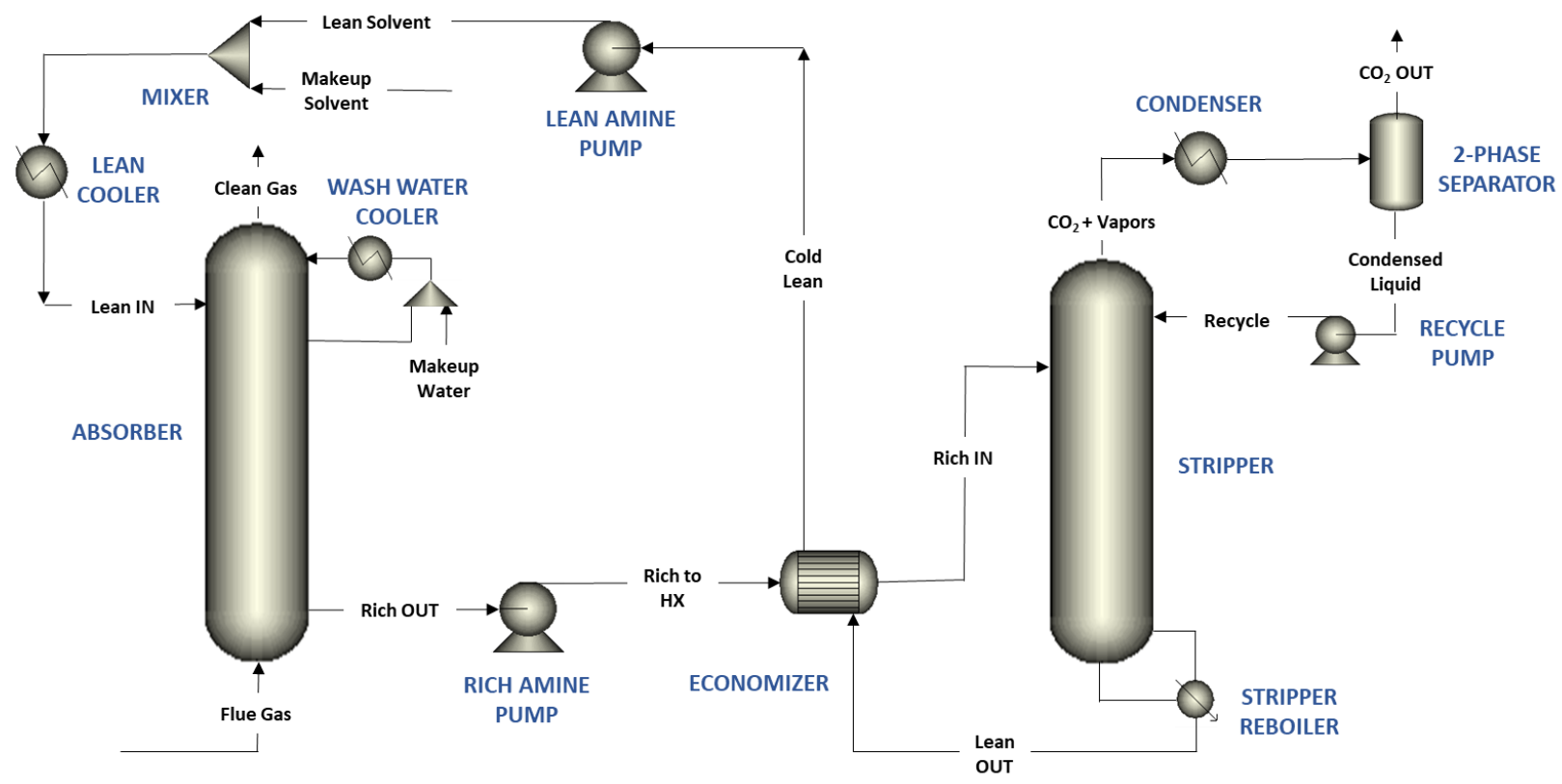

Fig. 2. Baseline case $\mathrm{CO}_{2}$ capture process flowsheet.

\subsubsection{Baseline case for carbon dioxide pressurization}

The $\mathrm{CO}_{2}$ pressurization is an essential step to prepare the captured $\mathrm{CO}_{2}$ for transportation.

263 Conventionally, the $\mathrm{CO}_{2}$ is pressurized using multi-stage compression, which is taken as a $\mathrm{BC}$ in this study.

264 Each stage of the multi-stage compression comprises a compressor and intercooler, as shown in Fig. 3. The

265 number of stages required depends on the captured $\mathrm{CO}_{2}$ pressure $\left(\mathrm{P}_{\mathrm{In}}\right)$, target pressure $\left(\mathrm{P}_{\text {Out }}\right)$ and the stage 266 pressure ratio $\left(\mathrm{P}_{\mathrm{R}}\right)$. The process parameters taken for $\mathrm{CO}_{2}$ compression are tabulated in Table 4, while the 267 net electric power consumed in the conventional compression process ( $\mathrm{W}_{\mathrm{Comp}, \mathrm{BC}}$ ) is given by Eq. (4). 


$$
W_{\text {Comp }, B C}=\sum_{i=1}^{N} W_{\text {Comp }}
$$

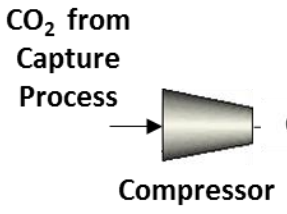

$\mathrm{CO}_{2}$

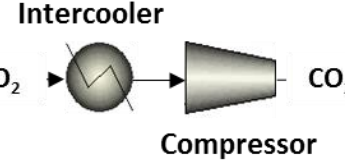

$\mathrm{CO}_{2}$

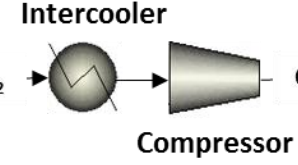

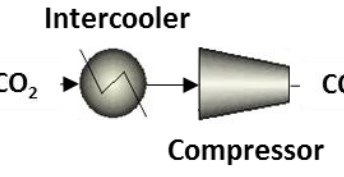

$\mathrm{CO}_{2}$

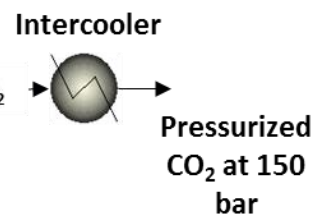

Fig. 3. Baseline case $\mathrm{CO}_{2}$ compression unit.

271

Table 4. Performance parameters of $\mathrm{CO}_{2}$ pressurization during multi-stage compression

\begin{tabular}{|c|c|}
\hline Parameters & Values \\
\hline Compressor and pump isentropic efficiency $(\eta)$ & 0.80 \\
\hline Captured $\mathrm{CO}_{2}$ pressure $\left(\mathrm{P}_{\mathrm{In}}\right)$ & $1.9[\mathrm{bar}]$ \\
\hline $\mathrm{CO}_{2}$ target pressure $\left(\mathrm{P}_{\text {Out }}\right)$ & $150[\mathrm{bar}]$ \\
\hline Cooling temperature $\left(\mathrm{T}_{\mathrm{C}}\right)$ & $30\left[{ }^{\circ} \mathrm{C}\right]$ \\
\hline Pinch point $(\mathrm{PP})$ & 5 \\
\hline Compressor pressure ratio $\left(\mathrm{P}_{\mathrm{R}}\right)$ across each stage & 3 \\
\hline
\end{tabular}

$274 \quad$ 2.4.1. Proposed carbon dioxide capture process configuration

This proposed novel configuration aims to reduce the heat required for the regeneration of amine solvent by the addition of a HP and integrating process waste heat within the system, as shown in Fig. 4.

277 The $\mathrm{CO}_{2}$-rich solution stream splits into two sub-streams before entering the economizer. One stream

278 follows the conventional path by entering the economizer and then moving to the stripper column. The other moves to the vapor heat exchanger and recovers heat from the hot $\mathrm{CO}_{2} / \mathrm{H}_{2} \mathrm{O}$ vapors mixture exiting the stripper top. This modification (shown with red lines in Fig. 4) will not only reduce the stripper duty, but also the condenser duty by recovering a part of the heat that was being wasted in the condenser. The solvent from the vapor heat exchanger enters the stripper and the $\mathrm{H}_{2} \mathrm{O} / \mathrm{CO}_{2}$ mixture moves to condenser. The stripper column is integrated with a pump-around heater (stripper inter-heater). Some of the solvent from the stripper column is withdrawn and the exchange heat in the stripper inter-heater is then pumped 
back to the stripper. Saturated steam at $130{ }^{\circ} \mathrm{C}$ is used as the heating utility in the stripper reboiler. The condensate from the reboiler outlet is used as a heating utility in the stripper inter-heater. The modification is marked with violet lines in Fig. 4.

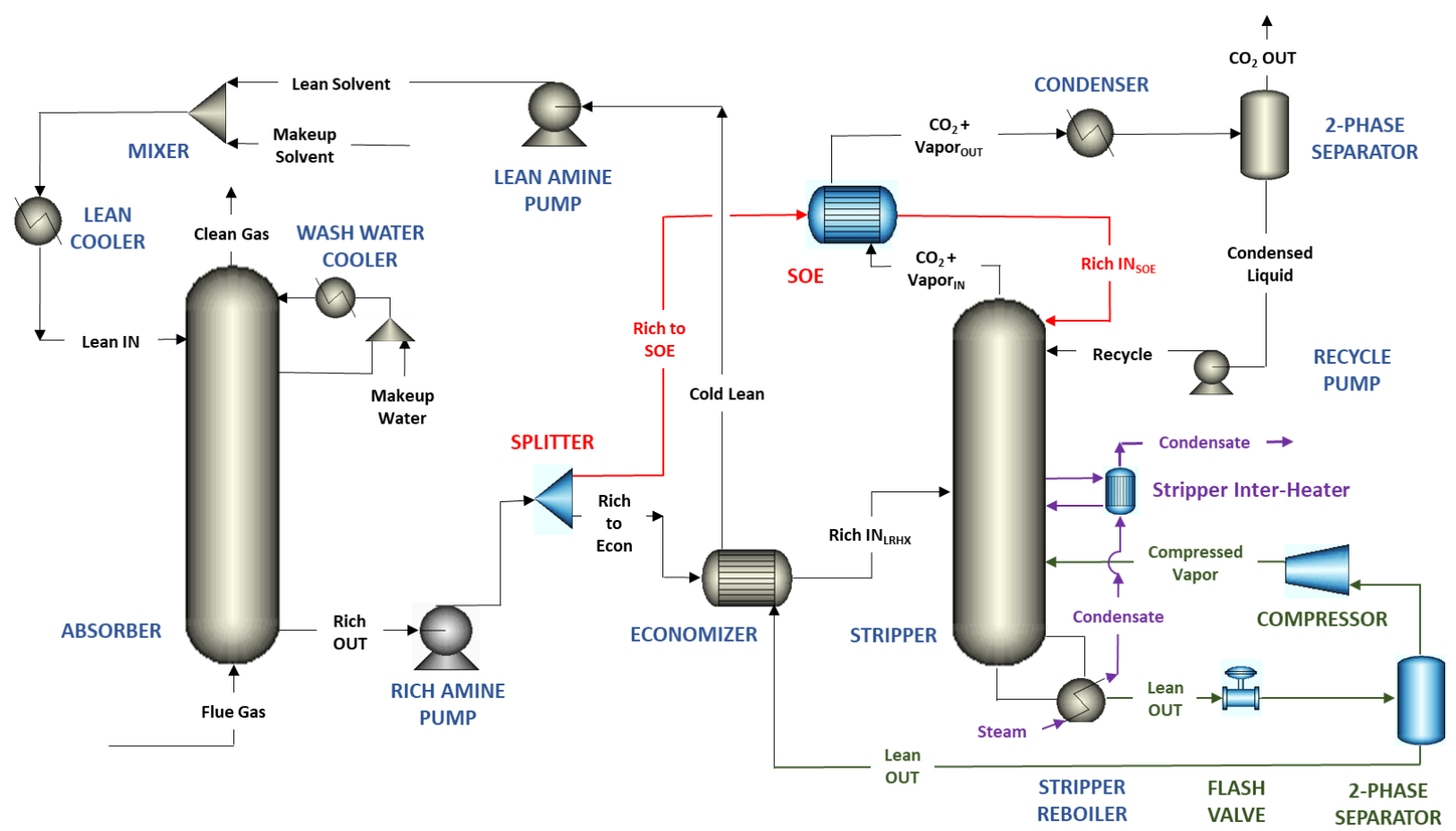

Fig. 4. Proposed $\mathrm{CO}_{2}$ capture process flowsheet.

$\mathrm{CO}_{2}$-lean solution from the stripper reboiler into the economizer, it was flashed in a two-phase separator, removing more $\mathrm{CO}_{2}$ and reducing the lean loading of the $\mathrm{CO}_{2}$-lean solution. The gas separated in the flash column was compressed back to the stripper pressure and returned to the stripper (as marked with green lines in Fig. 4). The lean solvent from the flash column was pumped to the economizer and further cooled before entering the absorber column. Even though additional electric power is needed to run the added compressor, the reduction in the reboiler's heat duty remains more prominent. For a reasonable comparison, the heat duty and electric power are brought to a common basis in terms of equivalent work, which is discussed later.

\subsubsection{Proposed design for the carbon dioxide pressurization process}

In the proposed pressurization schematics, the multi-stage compression is assisted by the HP system, as shown in Fig. 5. Increasing the pressure of the liquid $\mathrm{CO}_{2}$ is significantly less energy-intensive 
than gaseous compression. Therefore, the HP is used as a refrigeration cycle to liquefy the $\mathrm{CO}_{2}$, which is subsequently pumped to the required pressure.

The incoming $\mathrm{CO}_{2}$ from the capture unit is 1.9 bar, whereas the triple point pressure of $\mathrm{CO}_{2}$ is 5.17 bar. Therefore, the initial two stages of compression are necessary to raise the $\mathrm{CO}_{2}$ pressure beyond the triple point pressure. The HP system can thus be installed after either the second or third stages. This study evaluated the performance of the proposed design with HP installed after the second as well as third stage, which is discussed in Section 3.1.5.

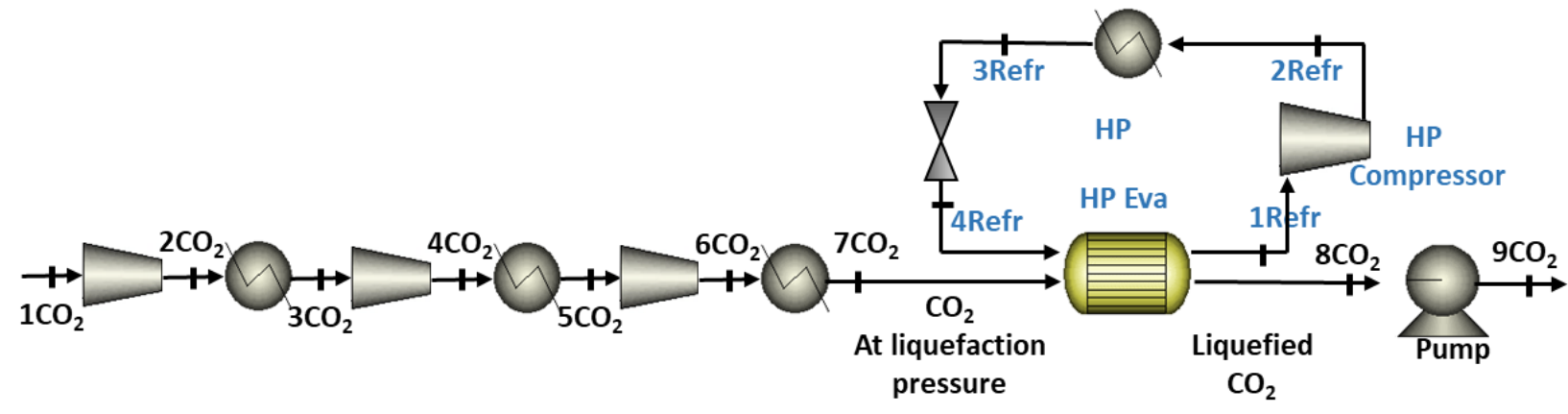

Fig. 5. Proposed heat pump assisted $\mathrm{CO}_{2}$ compression schematics.

The difference between the conventional and the proposed approach for $\mathrm{CO}_{2}$ pressurization is 311 elucidated in a P-h diagram in Fig. 6. The baseline approach is multi-stage compression while in the 312 proposed case the last stage is replaced by $\mathrm{CO}_{2}$ liquefaction and subsequent pumping to the target pressure.

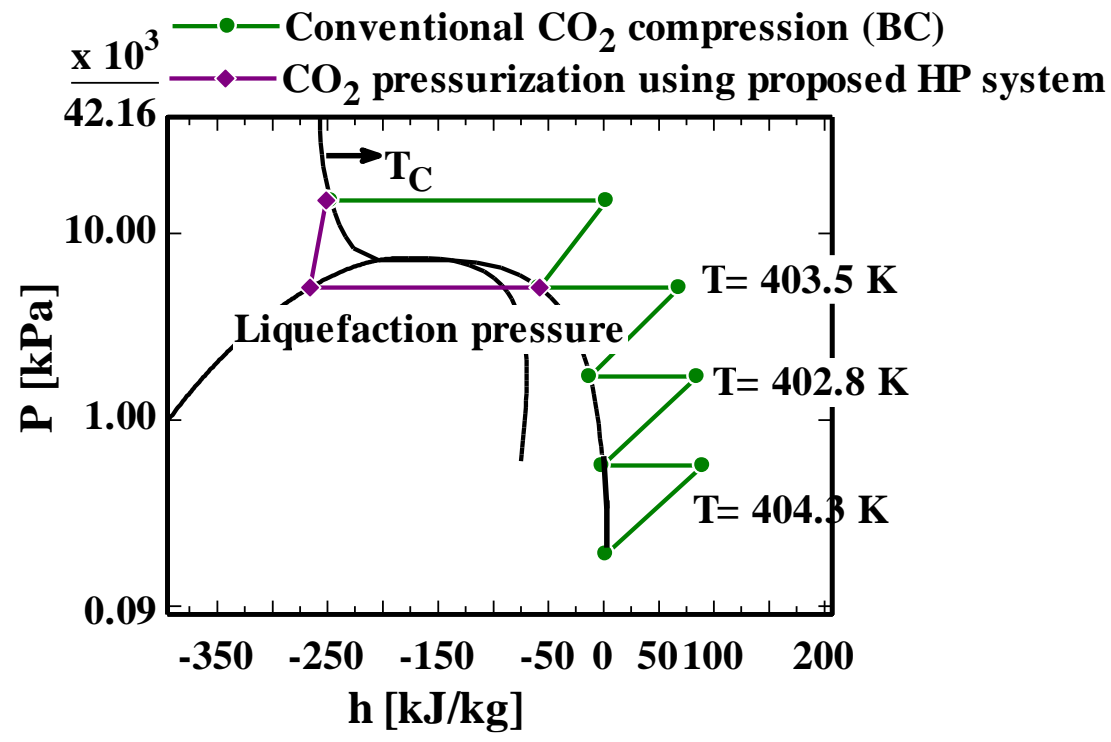

Fig. 6. Thermodynamic routes for $\mathrm{CO}_{2}$ pressurization. 


\subsubsection{Modelling framework for proposed carbon dioxide pressurization process}

.

The refrigerant of the HP, which absorbs heat $\left(\mathrm{Q}_{\mathrm{Eva}}\right)$ from the $\mathrm{CO}_{2}$, is then compressed and adjusted to expel heat into the environment. Propane (R290) is considered as the HP refrigerant in this study. In the evaporator, the saturation parameters of R290 are determined by the pinch point (PP) limit and $\mathrm{CO}_{2}$ liquefaction temperature. The $\mathrm{CO}_{2}$ liquefaction temperature is the saturation temperature, corresponding to its liquefaction pressure $\left(\mathrm{P}_{7 \mathrm{CO} 2}\right)$. State 1Refr in Fig. 5 is determined by identifying the refrigerant's saturation temperature in the evaporator and assuming a degree of superheating (SH) at the HP's compressor inlet. The ambient conditions, which are considered the heat sink for R290, determine the saturation temperature and pressure of R290 in the condenser and, consequently, the State 3Refr. State 2 Refr and 4Refr were determined by using a compressor model with isentropic efficiency and assuming isenthalpic expansion.

The calculation procedure of the HP system in the proposed schematics is summarized in Table 5. The discretization scheme is used for the modeling of heat exchangers, details of which can be found in [39]. The net power consumed in the proposed schematics $\left(\mathrm{W}_{\mathrm{Net}, \mathrm{PC}}\right)$ is given by $\mathrm{Eq}$. (5), where $\mathrm{W}_{\mathrm{Comp}, \mathrm{CO} 2 \text {, }}$ $\mathrm{W}_{\text {Pump }}$ and $\mathrm{W}_{\text {Comp,Refr }}$ are the power consumed by the initial multi-stage $\mathrm{CO}_{2}$ compressors, the $\mathrm{CO}_{2}$ pump and the HP compressor, respectively.

$$
W_{N e t, P C}=W_{\text {Comp }, \mathrm{CO} 2}+W_{P u m p}+W_{\text {Comp }, \text { Refr }}
$$

1

2

3

4

5


Table 5. Calculation schematics of the proposed heat pump system

\begin{tabular}{|c|c|c|c|c|c|}
\hline Step & State & Temperature & Pressure & Enthalpy & Comments \\
\hline 1 & $7 \mathrm{CO}_{2}$ & $\mathrm{~T}_{7 \mathrm{CO} 2}=\mathrm{T}_{\mathrm{C}}$ & $\mathrm{P}_{7 \mathrm{CO} 2}$ & $\mathrm{f}\left(\mathrm{T}_{7 \mathrm{CO} 2}, \mathrm{P}_{7 \mathrm{CO} 2}\right)$ & $\begin{array}{l}\text { Using the set values of } \mathrm{P}_{\mathrm{R}}, \mathrm{T}_{\mathrm{C}} \text {, } \\
\text { and } \eta_{\text {Comp }} ; \text { State } 7 \mathrm{CO}_{2} \text { is } \\
\text { solved. }\end{array}$ \\
\hline 2 & $8 \mathrm{CO}_{2}$ & $\begin{array}{c}\mathrm{T}_{8 \mathrm{CO} 2}=\mathrm{T}_{\mathrm{Sat}, 8 \mathrm{CO} 2} \\
=\mathrm{f}\left(\mathrm{P}_{8 \mathrm{CO} 2}\right)\end{array}$ & $\mathrm{P}_{8 \mathrm{CO} 2}=\mathrm{P}_{7 \mathrm{CO} 2}$ & $\mathrm{f}\left(\mathrm{T}_{8 \mathrm{CO} 2}, \mathrm{X}=0\right)$ & $\begin{array}{l}\text { Calculate } \mathrm{Q}_{\text {Eva }} \text { using heat } \\
\text { exchanger model. }\end{array}$ \\
\hline 3 & $9 \mathrm{CO}_{2}$ & $\begin{array}{c}\mathrm{T}_{9 \mathrm{CO} 2}=\mathrm{f}\left(\mathrm{P}_{9 \mathrm{CO} 2},\right. \\
\left.\eta_{\text {Pump }}\right)\end{array}$ & $\mathrm{P}_{9 \mathrm{CO} 2}$ & $\mathrm{f}\left(\mathrm{T}_{9 \mathrm{CO} 2}, \mathrm{P}_{9 \mathrm{CO} 2}\right)$ & Pump model. \\
\hline 4 & 1Refr & $\begin{array}{c}T_{1 \text { Refr }}=f\left(T_{\text {Sat }, 4 \text { Refr }},\right. \\
S H)\end{array}$ & $\begin{array}{c}P_{1 \text { Refr }}=P_{\text {Sat } 1 \text { Refr }}= \\
f\left(T_{4 \text { Refr }}\right)\end{array}$ & $\mathrm{f}\left(\mathrm{P}_{1 \text { Refr }}, \mathrm{T}_{1 \text { Refr }}\right)$ & $\mathrm{SH}$ is taken as $5 \mathrm{~K}$. \\
\hline 5 & $2 \operatorname{Refr}$ & $\begin{array}{c}\mathrm{T}_{2 \text { Refr }}=\mathrm{f}\left(\mathrm{P}_{\text {Sat }, 2 \text { Refr }},\right. \\
\left.\eta_{\text {Comp }}\right)\end{array}$ & $\begin{array}{c}P_{2 \text { Refr }}=P_{\text {Sat } 2 \text { Refr }}= \\
f\left(T_{3 \text { Refr }}\right)\end{array}$ & $\mathrm{f}\left(\mathrm{P}_{2 \text { Refr }}, \mathrm{T}_{2 \text { Refr }}\right)$ & Compressor model. \\
\hline 6 & 3Refr & $\begin{array}{c}\mathrm{T}_{3 \text { Refr }}=\mathrm{T}_{\text {Sat }, 3 \text { Refr }}= \\
\mathrm{T}_{\mathrm{C}}\end{array}$ & $\mathrm{P}_{3 \text { Refr }}=\mathrm{P}_{\text {Sat }, 3 \text { Refr }}$ & $\mathrm{f}\left(\mathrm{T}_{\text {Sat }, 3 \mathrm{Refr},}, \mathrm{X}=0\right)$ & Heat exchanger model. \\
\hline 7 & 4Refr & $\begin{array}{c}\mathrm{T}_{4 \mathrm{Refr}}=\mathrm{T}_{\text {Sat }, 4 \mathrm{Refr}}= \\
\mathrm{f}\left(\mathrm{T}_{8 \mathrm{CO} 2}, \mathrm{PP}\right)\end{array}$ & $\begin{array}{c}P_{4 \text { Refr }}=P_{\text {Sat }, 4 \text { Refr }}= \\
f\left(T_{4 \text { Refr }}\right)\end{array}$ & $\mathrm{f}\left(\mathrm{P}_{4 \mathrm{Refr}}, \mathrm{h}_{3 \mathrm{Refr}}\right)$ & Isenthalpic expansion. \\
\hline
\end{tabular}

342

\subsubsection{Proposed heat pump pressurization process integration with supercritical carbon dioxide cycle}

During the multi-stage $\mathrm{CO}_{2}$ compression, the temperature of the $\mathrm{CO}_{2}$ at each compressor outlet can reach around $400 \mathrm{~K}$, as is shown in Fig. 6. To make use of this temperature, an innovative scheme of $\mathrm{CO}_{2}$ liquefaction and pumping integrated with the $\mathrm{sCO}_{2}$ cycle, as displayed in Fig. 7 is proposed. In contrast to the ORC, the $\mathrm{sCO}_{2}$ cycle is designed to utilize the intercooling heat, as no additional working fluid is required to operate the $\mathrm{sCO}_{2}$ cycle. As can be seen in Fig. 7, the heat source and cycle working fluid are both $\mathrm{CO}_{2}$, and therefore a better temperature match is achieved by employing an $\mathrm{sCO}_{2}$ cycle. In addition, as the captured $\mathrm{CO}_{2}$ is liquefied using the HP system, therefore the high-pressure level required to operate an $\mathrm{sCO}_{2}$ cycle which is generally in the range of 150-250 bar can be attained in an energy-efficient manner by means of the pump. For the integrated design, $\mathrm{CO}_{2}$ from the State $8 \mathrm{CO}_{2}$ is initially pressurized to 200 bar and State $9 \mathrm{CO}_{2}$. The high-pressure $\mathrm{CO}_{2}$ is later divided into three streams, the flowrates of which are given in Fig. 7. The splitting of the total flow is performed in such a way so that the temperature of the 


$$
W_{\text {Net }, P C}=W_{\text {Comp }, \mathrm{CO} 2}+W_{\text {Pump }}+W_{\text {Comp }, \text { Refr }}-W_{\text {Net }, \text { Cycle }}
$$
streams after heating at States $10 \mathrm{CO}_{2}, 10 \mathrm{CO}_{2}{ }^{\prime}$ and $10 \mathrm{CO}_{2}{ }^{\prime \prime}$ is comparable. Thereafter, the streams are mixed $\left(\right.$ State $\left.11 \mathrm{CO}_{2}\right)$ and subsequently fed into a turbine to produce electric power.

For the $\mathrm{sCO}_{2}$ power generation, the turbine power output is $\mathrm{W}_{\text {Turb }}$ and the power consumed by the compressor to recover the pressure from State $13 \mathrm{CO}_{2}$ to $14 \mathrm{CO}_{2}$ and complete the process is $\mathrm{W}_{\mathrm{Comp} 2 \mathrm{CO} 2}$. The net power of the $\mathrm{sCO}_{2}$ cycle is expressed in Eq. (6).

$$
W_{\text {Net, }, \text { ycle }}=W_{\text {Turb }}-W_{\text {Comp } 2, C O 2}
$$

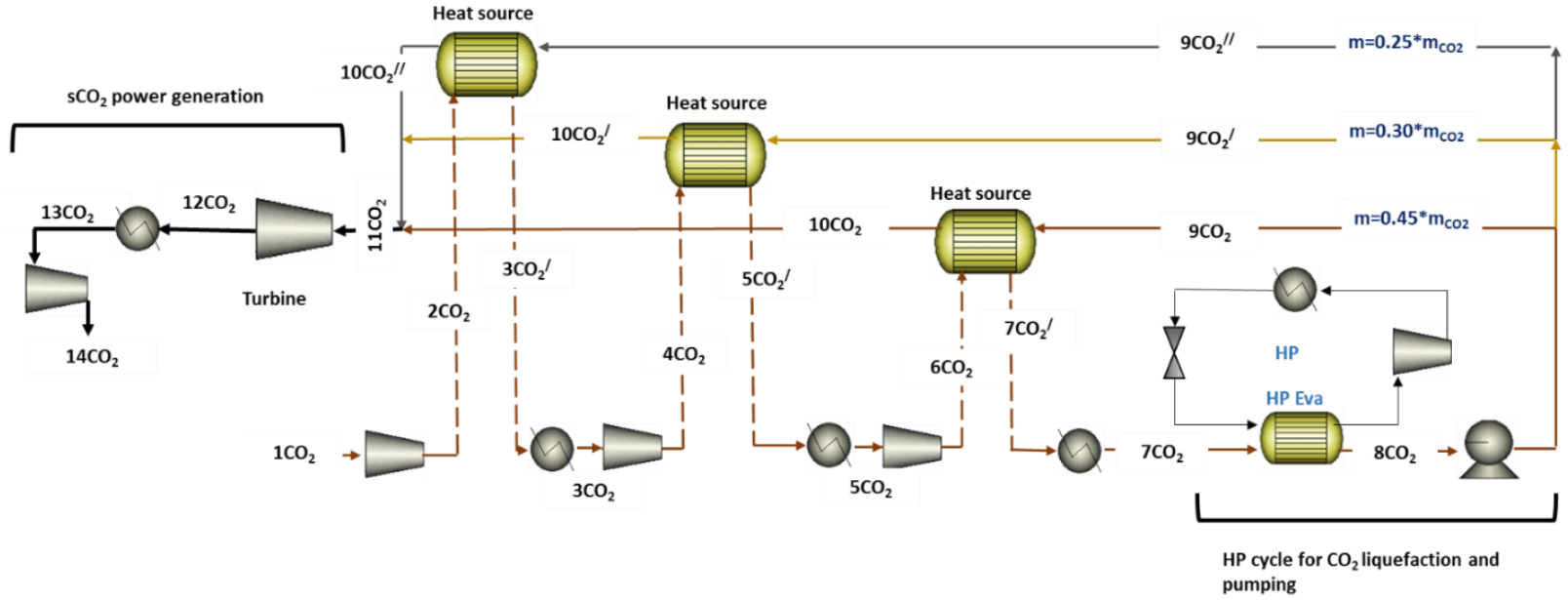

Fig. 7. Heat pump system integrated with a supercritical $\mathrm{CO}_{2}$ cycle.

\subsection{Total equivalent work/performance indicator calculation}

In the CCS process, two different energy expenditures are incurred: (i) the electrical power consumed in the pumps and compressors; and (ii) the heat duty in the boiler. For a fair comparison, a common basis for the two types of energy is needed, and therefore $\mathrm{W}_{\mathrm{Eq}}$ is defined for a performance comparison. The $\mathrm{W}_{\mathrm{Eq}}$ for the base and the proposed configurations are calculated using Eq. (8): 


$$
W_{E q}=\sum \eta_{\text {Turb }} * Q_{i}\left(\left(T_{i}+10[K]-T_{\text {Sink }}\right) /\left(T_{i}+10[K]\right)\right)+W_{\text {Eelctric }}
$$

372

373

374

375

The calculation flow chart of the complete CCS configuration proposed is summarized in Fig. 8.

where the turbine efficiency ( $\eta_{\text {Turb }}$ ) is considered to account for the non-ideal expansion, $T_{i}$ is the reboiler temperature $(\mathrm{K})$, the temperature of the steam in the reboiler is $10{ }^{\circ} \mathrm{C}$ higher than $\mathrm{T}_{\mathrm{i}}, \mathrm{Q}_{\mathrm{i}}$ is the reboiler duty for the base and proposed case $\left(\mathrm{GJ} / \mathrm{TonneCO} \mathrm{CO}_{2}\right)$ and $\mathrm{W}_{\text {Electric }}$ is the net electric power consumed during the complete CCS process. All the power entities, electric power and heat, consumed in the base as well as the proposed case, are converted to $\mathrm{W}_{\mathrm{Eq}}$ using Eq. (8). After calculating the total equivalent work for the base $\left(\mathrm{W}_{\mathrm{Eq}, \mathrm{BC}}\right)$ and the proposed case $\left(\mathrm{W}_{\mathrm{Eq}, \mathrm{PC}}\right)$, the net effect $\left(\phi_{\mathrm{Net}}\right)$ of the proposed schematics is defined as:

$$
\phi_{N e t}=\left(W_{E q, B C}-W_{E q, P C}\right) / W_{E q, B C}
$$

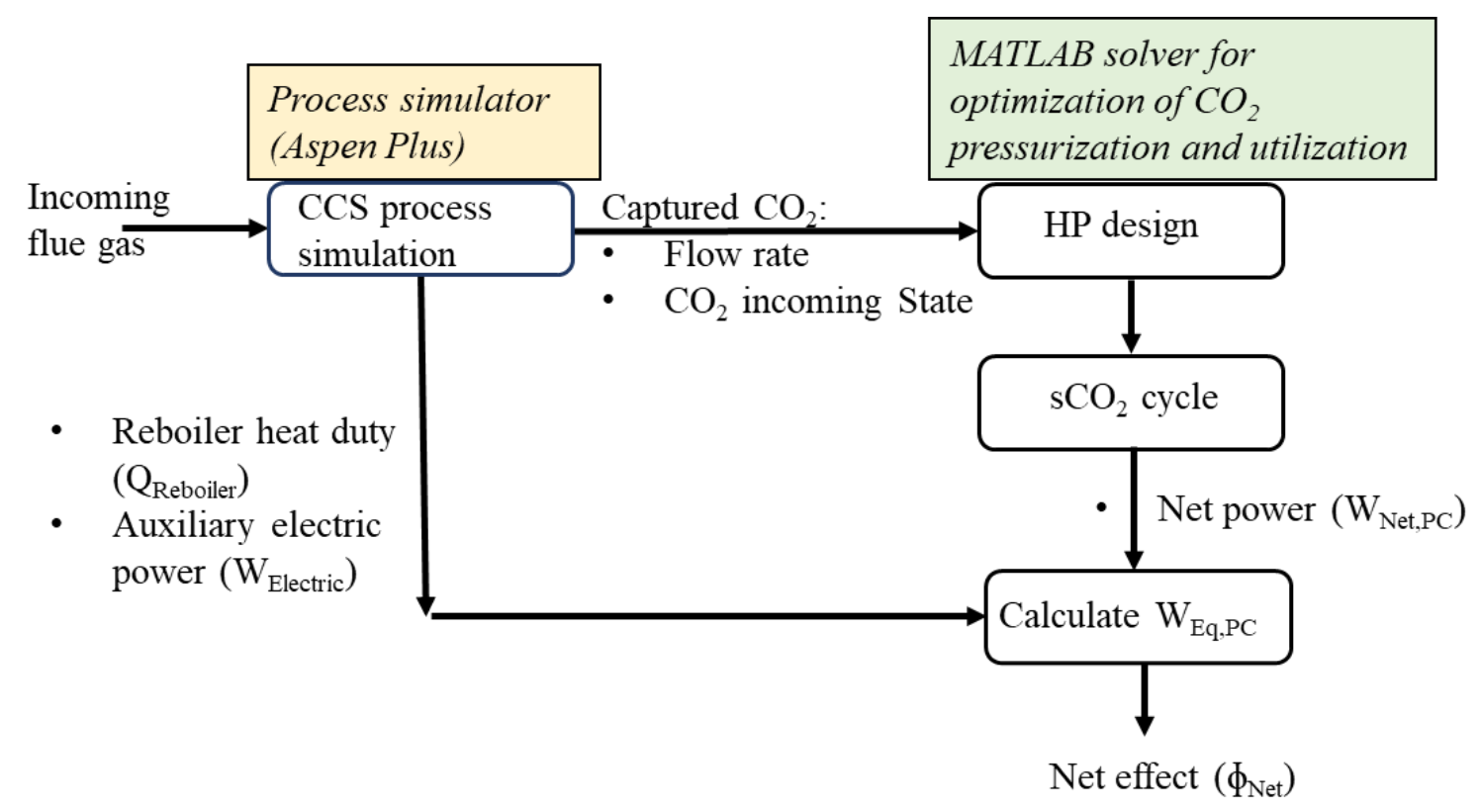

Fig. 8. Calculation flowchart of the proposed carbon capture and storage process configuration.

\section{Results and discussion}

Initially, the $\mathrm{BC}$ was simulated to calculate the reboiler duty, which amounted to 3.36 
increase the pressure of $\mathrm{CO}_{2}$ from 1.9 to 150 bar. After quantifying the $\mathrm{BC}$, the capture process design is

387 optimized for: split fraction, flash pressure, stripper inter-heater location and stripper inter-heater solvent

388 flowrate. The HP-assisted $\mathrm{CO}_{2}$ compression integrated with the $\mathrm{sCO}_{2}$ power cycle is optimized to yield the

389 best performance.

390

391

392

393

394

395

396

397

398

399

400

401

402

\section{3}

404

405

406

407

\subsection{Split ratio}

The $\mathrm{CO}_{2}$-rich stream is split to enhance the heat integration within the $\mathrm{CO}_{2}$ capture process. The objective is to recover maximum heat from the top and bottom streams, leaving the stripper. The amount of heat recovered from any of these streams depends on the $\mathrm{CO}_{2}$-rich solvent flowrate against the respective heat exchanger. The split ratio to the economizer was varied from 0.65 to 0.74 in order to study the effect on the stripper reboiler duty. Fig. 9 shows that 0.67 is the optimum split ratio, which corresponds to the minimum reboiler duty. The split ratio below 0.67 reduces the $\mathrm{CO}_{2}$-rich solvent flowrate to the economizer and the heat recovered in it. Although heat recovery in the vapor heat exchanger increases due to a higher $\mathrm{CO}_{2}$-rich solvent flowrate, the sum of the total heat recovery in the economizer and vapor heat exchanger is lower than at the split ratio of 0.67 . Similarly, above the 0.67 split ratio, the economizer can recover more heat, but the heat recovery in the vapor heat exchanger declines. The overall impact is the reduction in total heat recovery. The split ratio of 0.67 is the optimum split ratio at which the overall heat recovered in the economizer and vapor heat exchangers is at a maximum and the stripper reboiler duty is minimal.

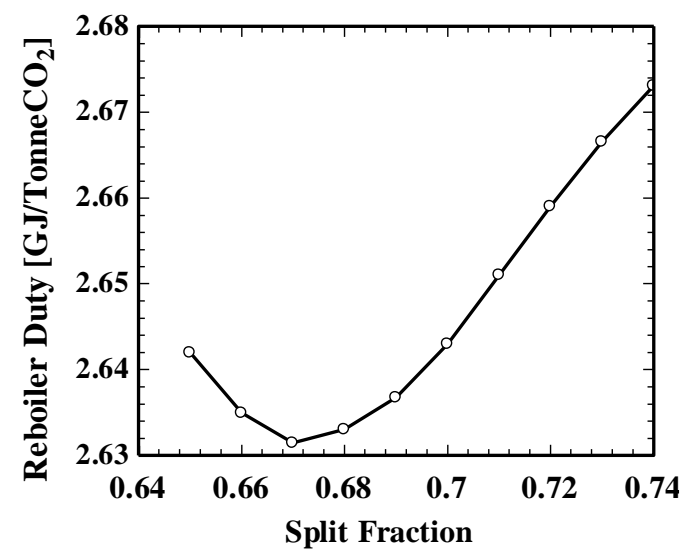

Fig. 9. Reboiler duty variation with split fraction.

\subsection{Flash pressure}

Lean solvent from the stripper reboiler is flashed in a column to strip out the $\mathrm{CO}_{2}$, which is compressed back to the stripper pressure. Additional electrical energy is required for the compression of $\mathrm{CO}_{2}$. The amount of energy required for compression depends on the flashing pressure. However, this additional energy increases the temperature of $\mathrm{CO}_{2}$ which, upon returning to the stripper, not only adds 
energy to the stripper but also acts as a mass and energy stripping agent and reduces the stripper duty. Fig. 10 shows the impact of flash pressure on the compression energy requirement and the stripper reboiler duty. As the reboiler duty is in the form of heat energy and the compressor duty is in the form of electric work, $\mathrm{W}_{\mathrm{Eq}}$, is used as the key parameter to determine the optimum flash pressure (Eq. (8)). The impact of the flash pressure on $\mathrm{W}_{\mathrm{Eq}}$ is shown in Fig. 11, which reveals that 1.3 bar is the optimum flash pressure and corresponds to the minimum total $\mathrm{W}_{\mathrm{Eq}}$.

Fig. 10. Effect of the flash pressure on reboiler duty and compressor power.

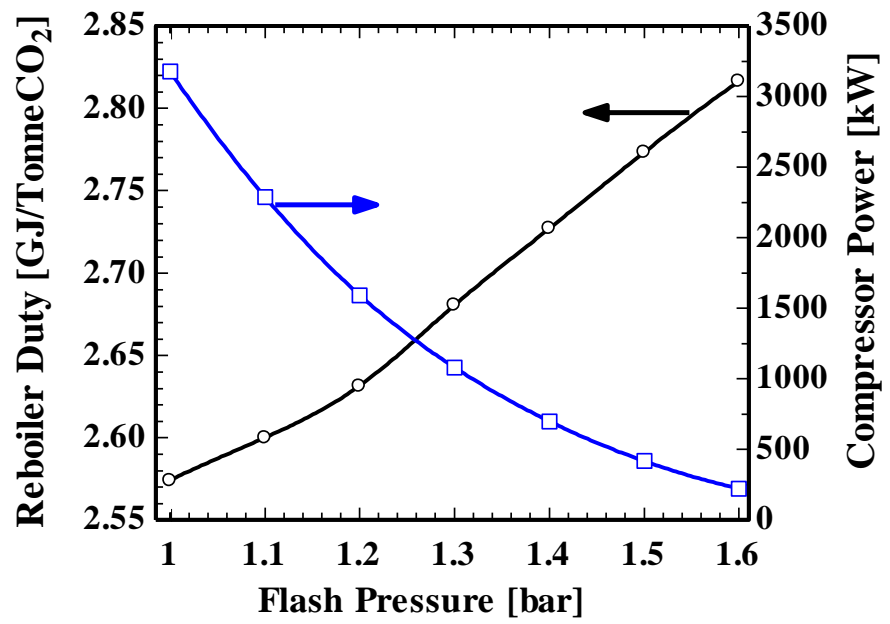

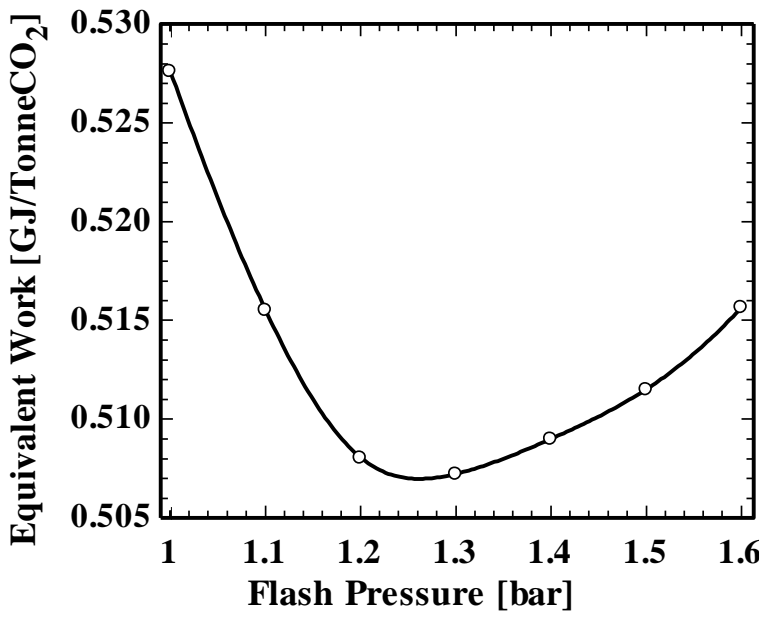

Fig. 11. Effect of the flash pressure on equivalent work.

\subsection{Stripper inter-heater location}

Saturated steam, used as the reboiler heating utility, exits as condensate at $129{ }^{\circ} \mathrm{C}$. To recover heat from the reboiler condensate, stripper inter-heater is introduced. The stripper has 20 stages. Rich amine is fed from the top (stage 1) while lean solvent leaves from the bottom (stage 20). Amine solvent from a higher stripper stage is withdrawn and heated in a stripper inter-heater using reboiler condensate, and is fed back to a lower stage. To find the optimal withdrawal and feedback location, the withdrawal and feedback stage was varied, and the stripper duty observed.

Fig. 12 shows the impact of withdrawal and feedback stage on the stripper reboiler duty. The liquid at the top stages of the stripper column is at a relatively lower temperature and, therefore, has a high temperature difference from the reboiler condensate and can thus recover more heat. Withdrawal from the lower stage results in a lower temperature difference from the reboiler condensate and, consequently, less heat can be recovered.

As the $\mathrm{CO}_{2}$-rich solvent is heated in the inter-heater, the $\mathrm{CO}_{2}$ gas and water vapors begin separating from the solvent. When this vapor-liquid mixture is fed back to a lower stage, the vapor phase interacts 
with more liquid coming down and strips more $\mathrm{CO}_{2}$ from the $\mathrm{CO}_{2}$-rich solvent, thus reducing the reboiler 429 duty. Stage 2 is the optimum withdrawal location and stage 15 the optimum feedback stage. Feeding below 430 stage 15 does not induce any substantial change in reboiler duty.

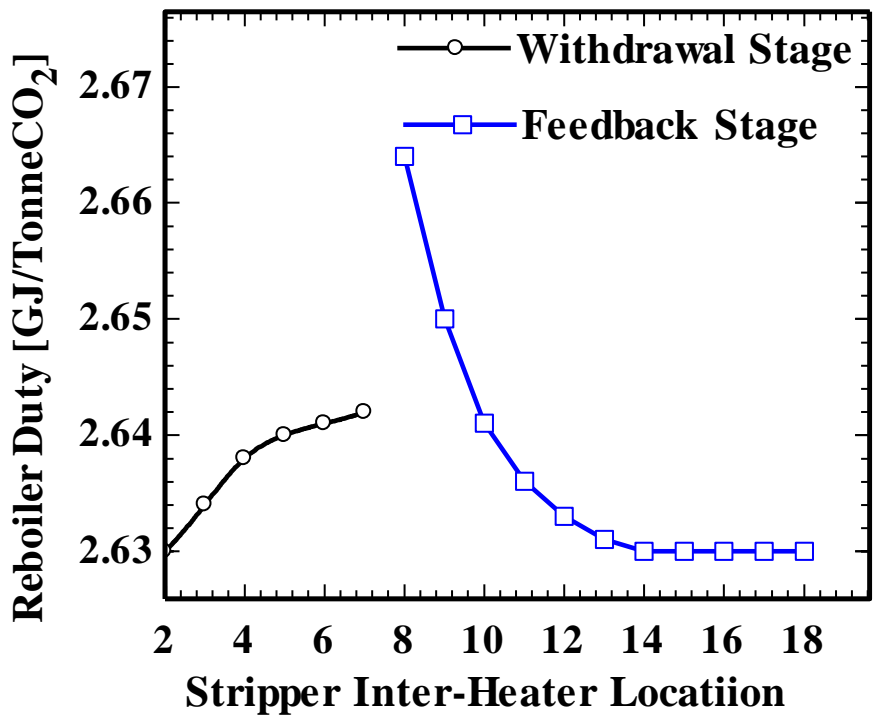

Fig. 12. Stripper inter-heater location optimization.

\subsection{Stripper inter-heater flowrate}

Hot solvent from the stripper inter-heater, when fed back to the stripper, serves as a stripping agent. The effectiveness of the stripping agent improves at higher temperature and reduces the reboiler duty [40]. Eq. (10) shows that higher temperatures $\left(\Delta \mathrm{T}_{\text {solvent }}\right)$ can be achieved by reducing the solvent flowrate 437 inter-heater should not exceed $120^{\circ} \mathrm{C}$.

In order to find the optimum flowrate at which the reboiler duty is at a minimum and the solvent temperature is below the degradation temperature $\left(120^{\circ} \mathrm{C}\right)$, the $\mathrm{m}_{\text {solvent }}$ to stripper inter-heater was reduced from $3000 \mathrm{kmol} / \mathrm{hr}$ to $1000 \mathrm{kmol} / \mathrm{hr}$ and its impact on the reboiler duty and solvent outlet temperature was evaluated. Fig. 13 shows that by reducing the inter-heater flowrate, the temperature of the solvent fed back

442 to stripper increases, which also improves the stripping efficiency and reduces the reboiler duty. However, 443 due to the solvent degradation temperature limit, $1750 \mathrm{kmol} / \mathrm{hr}$. is considered the optimum $\mathrm{m}_{\text {solvent, }}$ which 444 corresponds to a stripper inter-heater solvent temperature of below $120{ }^{\circ} \mathrm{C}$ and a lower reboiler duty.

$$
Q=m_{\text {solvent }} \times c_{p} \times \Delta T_{\text {solvent }}
$$




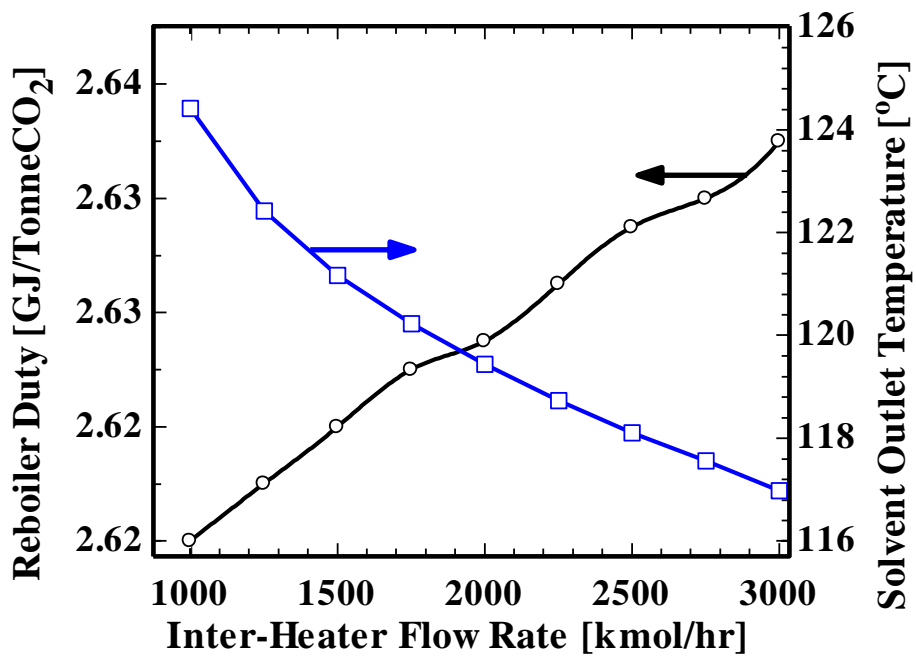

Fig. 13. Effect of stripper inter-heater flowrate on reboiler duty and solvent temperature.

\subsection{Optimizing the carbon dioxide pressurization process}

The proposed pressurization process aims to reduce the required electric power to raise the $\mathrm{CO}_{2}$ pressure by replacing one or two stages of $\mathrm{CO}_{2}$ compressors with an HP system, consequently reducing

$450 \mathrm{~W}_{\mathrm{Comp}, \mathrm{CO} 2}$. However, due to the application of HP, another source of electric power consumption becomes

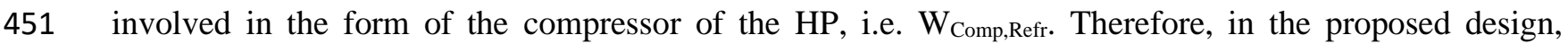
$452 \mathrm{~W}_{\mathrm{Comp}, \mathrm{CO} 2}$ and $\mathrm{W}_{\text {Comp,Refr }}$ are in a trade-off relationship. Table 6 summarizes the performance of the proposed 453 design with the HP installed after the second and third stage of the compressors. Installing the HP after the 454 third stage of the compressor instead of the second will seemingly increase the $\mathrm{W}_{\text {Comp,CO2. However, as can }}$ 455 be seen in the table, the $\mathrm{W}_{\text {Comp,CO2 }}$ increases up to $46.49 \%$. At the same time, however, the $\mathrm{W}_{\text {Comp,Refr }}$ is reduced by $85.80 \%$ while the difference in $\mathrm{W}_{\text {Pump }}$ remains negligible.

Table 6. Performance evaluation with the heat pump installed after the second and the third stages of compressors.

\begin{tabular}{|l|c|c|c|c|}
\hline \multicolumn{1}{|c|}{ New Design } & $\begin{array}{c}\text { Liquefaction } \\
\text { Pressure [kPa] }\end{array}$ & $\begin{array}{c}\mathbf{C O}_{2} \text { Multistage } \\
\text { Compression } \\
\left(\mathbf{W}_{\text {Comp,C02 })[k W]}\right.\end{array}$ & $\begin{array}{c}\mathbf{C O}_{2} \text { Pump } \\
\left(\mathbf{W}_{\text {Pump }}\right) \\
{[\mathbf{k W}]}\end{array}$ & $\begin{array}{c}\text { HP-Compressor } \\
\left(\mathbf{W}_{\text {Comp,Refr }}\right) \\
{[\mathbf{k W}]}\end{array}$ \\
\hline $\begin{array}{l}\text { 2-Stage CO } \mathbf{C O}_{2} \\
\text { Compressor \& HP }\end{array}$ & $\mathrm{P}_{5 \mathrm{CO} 2}=1710$ & 9191.50 & 1130.70 & 7581.70 \\
\hline
\end{tabular}




\begin{tabular}{|l|c|c|c|c|}
\hline $\begin{array}{l}\text { 3-Stage CO} \\
\text { Compressor \& HP }\end{array}$ & $\mathrm{P}_{7 \mathrm{CO} 2}=5130$ & 13465.00 & 1149.00 & 1076.60 \\
\hline Percentage change & N/A & $+46.49 \%$ & $-1.62 \%$ & $-85.80 \%$ \\
\hline
\end{tabular}

The substantial decrease in $\mathrm{W}_{\text {Comp,Refr }}$ with the HP installed after the third stage is due to the combined reduction in refrigerant flowrate $\left(\mathrm{m}_{\text {Refr }}\right)$ and the $\mathrm{P}_{\mathrm{R}}$ across the HP's compressor. Table 7 tabulates

463 the $Q_{E v a}$, the saturation pressure of the refrigerant in the evaporator and condenser, the resulting $P_{R}$ and the

$464 \mathrm{~m}_{\text {Refr. }} \mathrm{Q}_{\text {Eva }}$ decreases and the saturation temperature of the refrigerant in the evaporator increases with the

465 increase in $\mathrm{CO}_{2}$ liquefaction pressures. Therefore, the $\mathrm{m}_{\mathrm{Refr}}$ and $\mathrm{P}_{\mathrm{R}}$ both decrease, leading to a considerable

466 reduction in $\mathrm{W}_{\text {Comp,Refr. }}$ The subsequent results and discussions are based on HP installed after the

467 third compressor stage.

Table 7. Operating characteristics of the heat pump system installed after the second and the third stages of 470 compressors.

\begin{tabular}{|c|c|c|c|c|c|c|}
\hline \multirow{2}{*}{ New Design } & \multirow{2}{*}{$\begin{array}{c}\text { Liquefaction } \\
\text { Pressure } \\
\text { [kPa] }\end{array}$} & \multirow{2}{*}{$\begin{array}{c}\text { Evaporator } \\
\text { heat load } \\
\left(Q_{\text {Eva }}\right)[k W]\end{array}$} & \multicolumn{2}{|c|}{$\begin{array}{c}\text { Refr. saturation } \\
\text { pressure [kPa] }\end{array}$} & \multirow{2}{*}{$\begin{array}{c}\text { Refr. flow } \\
\text { rate }\left(\mathbf{m}_{\text {Refr }}\right) \\
{[\mathrm{kg} / \mathrm{s}]}\end{array}$} & \multirow{2}{*}{$\begin{array}{l}P_{R} \text { across } \\
\text { HP's comp }\end{array}$} \\
\hline & & & Evaporator & Condenser & & \\
\hline $\begin{array}{c}\text { 2-Stage } \mathrm{CO}_{2} \\
\text { Compressor \& } \mathrm{HP}\end{array}$ & $\mathrm{P}_{5 \mathrm{CO} 2}=1710$ & 18461.54 & 171.16 & 1079.26 & 68.44 & 6.30 \\
\hline $\begin{array}{c}\text { 3-Stage } \mathrm{CO}_{2} \\
\text { Compressor \& } \mathrm{HP}\end{array}$ & $\mathrm{P}_{7 \mathrm{CO} 2}=5130$ & 10983.51 & 642.90 & 1079.26 & 34.72 & 1.68 \\
\hline Percentage change & N/A & $-40.51 \%$ & N/A & N/A & $-49.27 \%$ & $-73.33 \%$ \\
\hline
\end{tabular}

471

\section{3.6. The integrated supercritical carbon dioxide cycle optimization}

473 Due to the advantages discussed earlier, the compression heat is recovered using an integrated $\mathrm{sCO}_{2}$

474 cycle (Fig. 7). For an $\mathrm{sCO}_{2}$ cycle at a given turbine inlet temperature, an optimum $\mathrm{P}_{\mathrm{R}}$ across the turbine is

475 required to maximize the cycle performance [41]. In the analysis, the turbine inlet pressure $\left(\mathrm{P}_{11 \mathrm{CO}_{2}}\right)$ is fixed

476 to 200 bar, and hence the turbine outlet pressure $\left(\mathrm{P}_{12 \mathrm{CO} 2}\right)$ is parametrically investigated in this study. Fig.

47714 shows the variation of $\mathrm{W}_{\text {Net,Cycle }}$ with $\mathrm{P}_{12 \mathrm{CO} 2}$, while the individual variation of $\mathrm{W}_{\text {Turb }}$ and $\mathrm{W}_{\mathrm{Comp} 2, \mathrm{CO} 2}$ with 
$478 \mathrm{P}_{12 \mathrm{CO} 2}$ is shown in Fig. 15. As can be seen in Fig. 15, the $\mathrm{W}_{\text {Turb }}$ varies steadily throughout; however, the

$479 \mathrm{~W}_{\mathrm{Comp2}, \mathrm{CO} 2}$ experienced a sharp decrease at the start, with $\mathrm{P}_{12 \mathrm{CO} 2}$. The sudden reduction of $\mathrm{W}_{\mathrm{Comp2,CO} 2}$ is due

480 to the operation of the compressor near the critical point where the properties of $\mathrm{CO}_{2}$ substantially vary.

481 Fig. 16 shows the variation of $\mathrm{CO}_{2}$ density at the compressor inlet with $\mathrm{P}_{12 \mathrm{CO} 2}$. The drastic initial increase

482 in $\mathrm{CO}_{2}$ density results in a sharp reduction of $\mathrm{W}_{\mathrm{Comp2,CO} 2}$, which causes the $\mathrm{sCO}_{2}$ power cycle to behave in

483 the manner presented in Fig. 14.

484

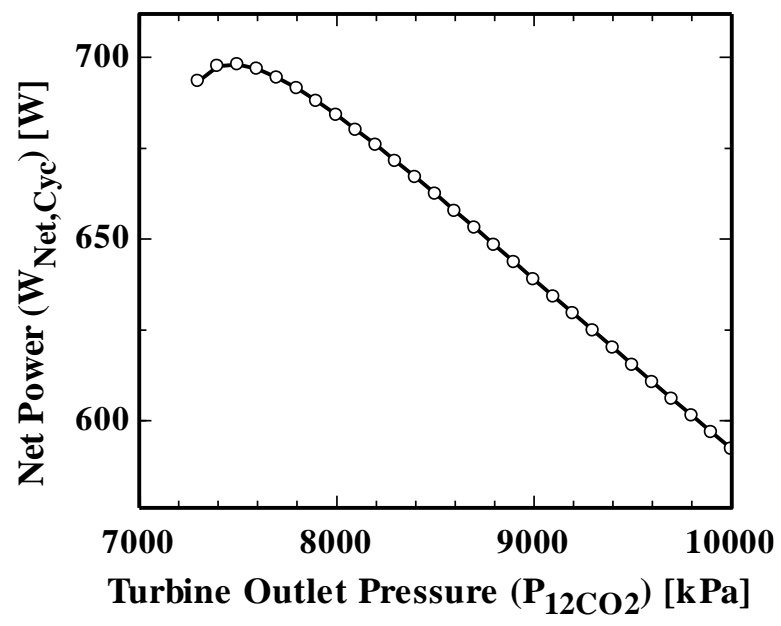

Fig. 14. Supercritical $\mathrm{CO}_{2}$ power generation $\left(\mathrm{W}_{\mathrm{Net}, \mathrm{Cycle}}\right)$ variation with turbine outlet pressure $\left(\mathrm{P}_{12 \mathrm{CO} 2}\right)$.
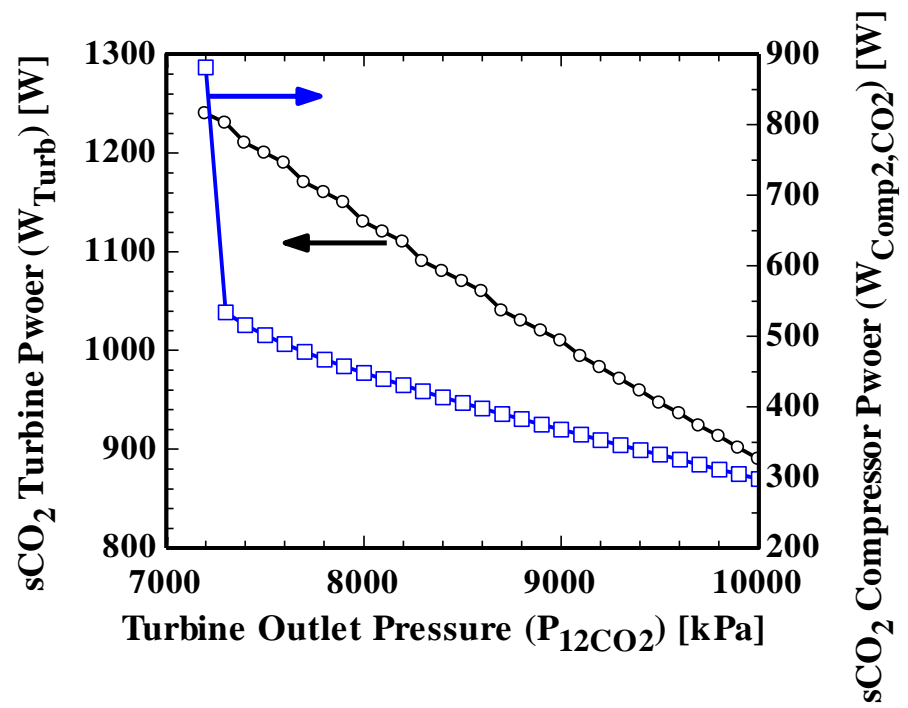

Fig. 15. Turbine power $\left(\mathrm{W}_{\text {Turb }}\right)$ and compressor power $\left(\mathrm{W}_{\mathrm{Comp} 2, \mathrm{CO} 2}\right)$ variation with turbine outlet pressure $\left(\mathrm{P}_{12 \mathrm{CO} 2}\right)$. 


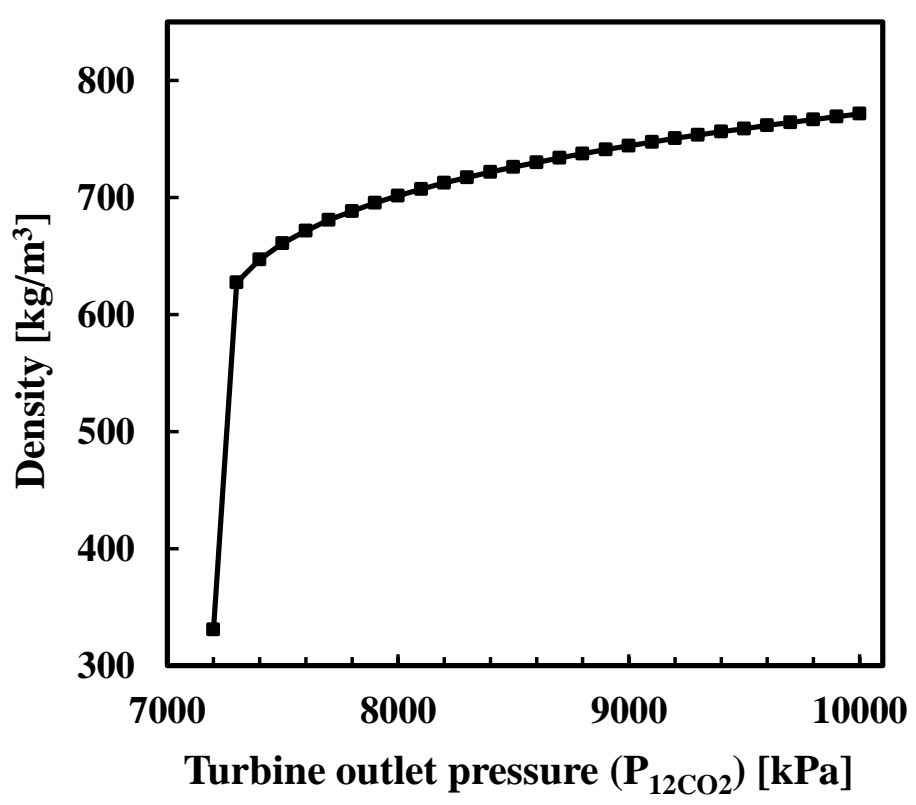

Fig. 16. Compressor inlet density variation with turbine outlet pressure $\left(\mathrm{P}_{12 \mathrm{CO} 2}\right)$.

487 P-h diagram in Fig. 17. For each intercooling stage, a certain amount of heat is recovered while that 488 remaining is ejected into the environment. A simple $\mathrm{sCO}_{2}$ rather the recuperative $\mathrm{sCO}_{2}$ cycle is integrated 489 to generate power, due to a low outlet temperature of the turbine $\left(\mathrm{T}_{12 \mathrm{CO} 2}\right)$.

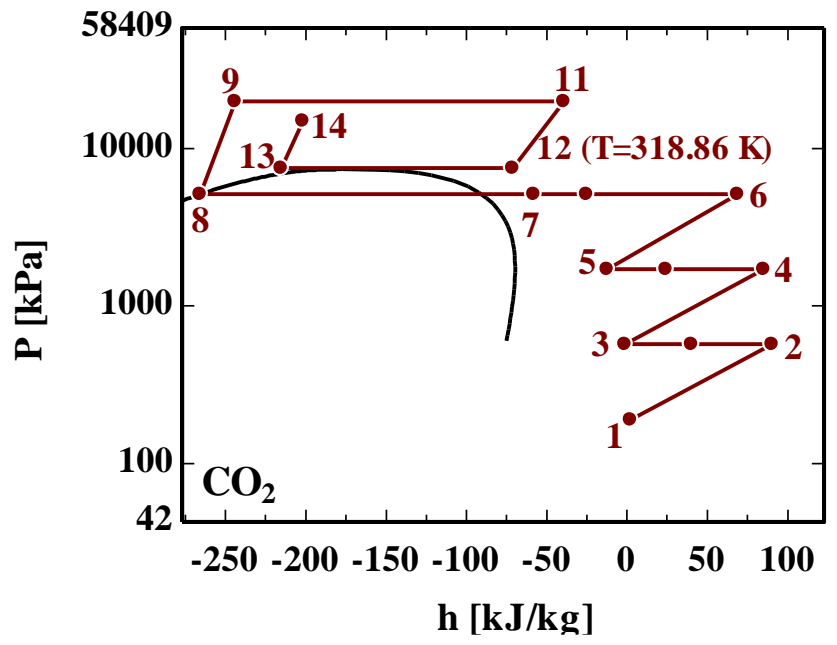

Fig. 17. Pathway of $\mathrm{CO}_{2}$ in the proposed pressurization process. 
The integrated $\mathrm{sCO}_{2}$ cycle generates a net power of $982.61 \mathrm{~kW}$, with a cycle efficiency ( $\left.\eta_{\text {Cycle }}\right)$ of $9.01 \%$ and a heat source temperature around $400 \mathrm{~K}$. Furthermore, the new design utilized the $\mathrm{CO}_{2}$ prior to storage, with no additional working fluid inventory required to operate the cycle. Table 8 summarizes the state of $\mathrm{CO}_{2}$ and R290, with the HP installed after the third stage.

Table 8. State properties of $\mathrm{CO}_{2}$ and $\mathrm{R} 290$ in the proposed pressurization process.

\begin{tabular}{|c|c|c|c|c|}
\hline State & Fluid & $\begin{array}{c}\text { Temperature } \\
{[\mathrm{K}]}\end{array}$ & Pressure [kPa] & $\begin{array}{c}\text { Enthalpy } \\
{[\mathrm{kJ} / \mathrm{kg}]}\end{array}$ \\
\hline $1 \mathrm{CO}_{2}$ & $\mathrm{CO}_{2}$ & 303.16 & 190 & 2.54 \\
\hline $2 \mathrm{CO}_{2}$ & $\mathrm{CO}_{2}$ & 402.45 & 570 & 90.46 \\
\hline $3 \mathrm{CO}_{2}^{\prime}$ & $\mathrm{CO}_{2}$ & 348.74 & 570 & 40.17 \\
\hline $3 \mathrm{CO}_{2}$ & $\mathrm{CO}_{2}$ & 303.16 & 570 & -0.95 \\
\hline $4 \mathrm{CO}_{2}$ & $\mathrm{CO}_{2}$ & 403.03 & 1710 & 85.27 \\
\hline $5 \mathrm{CO}_{2}^{\prime}$ & $\mathrm{CO}_{2}$ & 340.74 & 1710 & 24.47 \\
\hline $5 \mathrm{CO}_{2}$ & $\mathrm{CO}_{2}$ & 303.16 & 1710 & -12.15 \\
\hline $6 \mathrm{CO}_{2}$ & $\mathrm{CO}_{2}$ & 404.51 & 5130 & 68.83 \\
\hline $7 \mathrm{CO}_{2}^{\prime}$ & $\mathrm{CO}_{2}$ & 324.74 & 5130 & -25.01 \\
\hline $7 \mathrm{CO}_{2}$ & $\mathrm{CO}_{2}$ & 303.16 & 5130 & -57.65 \\
\hline $8 \mathrm{CO}_{2}$ & $\mathrm{CO}_{2}$ & 288.50 & 5130 & -265.75 \\
\hline $9 \mathrm{CO}_{2}$ & $\mathrm{CO}_{2}$ & 306.74 & 20000 & -244.00 \\
\hline $9 \mathrm{CO}_{2}^{\prime}$ & $\mathrm{CO}_{2}$ & 306.74 & 20000 & -244.00 \\
\hline $9 \mathrm{CO}_{2}^{\prime \prime}$ & $\mathrm{CO}_{2}$ & 306.74 & 20000 & -244.00 \\
\hline $10 \mathrm{CO}_{2}$ & $\mathrm{CO}_{2}$ & 394.14 & 20000 & -35.47 \\
\hline $10 \mathrm{CO}_{2}^{\prime}$ & $\mathrm{CO}_{2}$ & 391.21 & 20000 & -41.31 \\
\hline $10 \mathrm{CO}_{2}^{\prime \prime}$ & $\mathrm{CO}_{2}$ & 390.47 & 20000 & -42.80 \\
\hline $11 \mathrm{CO}_{2}$ & $\mathrm{CO}_{2}$ & 392.33 & 20000 & -39.06 \\
\hline $12 \mathrm{CO}_{2}$ & $\mathrm{CO}_{2}$ & 318.87 & 7500 & -71.04 \\
\hline $13 \mathrm{CO}_{2}$ & $\mathrm{CO}_{2}$ & 303.16 & 7500 & -215.00 \\
\hline $14 \mathrm{CO}_{2}$ & $\mathrm{CO}_{2}$ & 320.17 & 15000 & -201.70 \\
\hline 1Refr & R290 & 288.50 & 642.91 & 595.3 \\
\hline 2Refr & R290 & 313.17 & 1079.26 & 626.6 \\
\hline 3Refr & R290 & 303.16 & 1079.26 & 279.4 \\
\hline 4Refr & R290 & 283.50 & 642.91 & 279.4 \\
\hline
\end{tabular}

\section{Performance comparison based on equivalent work:}

After optimizing the capture and pressurization process, the $\mathrm{W}_{\mathrm{Eq}, \mathrm{PC}}$ is calculated using Eq. (8). Table 9 summarizes the power consumptions of the base and proposed case, as well as the $\phi_{\text {Net. }}$ The performance of the proposed system is reported at the optimized conditions. As Table 9 shows, the new design successfully reduces the boiler duty from 3.36 to $2.65 \mathrm{GJ} / \mathrm{TonneCO}$. The modifications to the capture process include optimizing the split ratio in the splitter, adding a heat exchanger as the stripper inter-heater and adding a compressor for the HP. The optimization of the split ratio reduces the reboiler's 

heat duty by achieving a better thermal match within the overhead heat exchanger and the economizer. For the stripper inter-heater, the condensate from the reboiler served as the heating utility and no additional heat source was required. The new capture process design involves an additional compressor in the HP, as discussed in section 3.1.2, which results in an additional electric power consumption of $1112 \mathrm{~kW}$. The detailed thermodynamic state properties of the complete proposed system are provided in the supplementary material (Appendix A and B).

The electric power requirement for $\mathrm{CO}_{2}$ pressurization was reduced from 16691 to $14708 \mathrm{~kW}$ using the $\mathrm{SCO}_{2}$ cycle-integrated HP liquefaction and pressurization system. The proposed CCS design results in a significant saving of $\phi_{\mathrm{Net}}=15.8 \%$ in equivalent work. The $\phi_{\mathrm{Net}}$ shows the unified impact of heat and electric power, while the individual saving on the heat duty and electric power is $21.1 \%$ and $5.22 \%$, respectively. This study is concerned with minimizing energy expenditure for the CCS process, which improves the prospects of CCS systems being deployed in the power plant sector. However, the reduction in energy consumption is achieved by adding a heat exchanger and a compressor to the capture process and assisting the compression chain with a $\mathrm{HP}$ refrigeration cycle and $\mathrm{sCO}_{2}$ cycle. The proposed pressurization system has the advantage of reducing a $\mathrm{CO}_{2}$ compressor stage, however, it involves an additional $\mathrm{HP}$ and $\mathrm{sCO}_{2}$ cycle footprint. To quantify the economic behavior of the proposed system would require detailed cost modeling of the capture process, the $\mathrm{CO}_{2}$ compression chain and HP system components. The current paper focuses on the energy expenditure of the proposed system, while the future outlook entails an economic assessment of the proposed design.

Table 9. Performance indicators of the base and the proposed system.

\begin{tabular}{|c|c|c|c|c|c|c|c|}
\hline & $\begin{array}{c}\text { Reboiler } \\
\text { Heat Duty } \\
{[\mathbf{G J} / \text { Tonne }} \\
\left.\mathbf{C O}_{2}\right]\end{array}$ & $\begin{array}{c}\text { Electric } \\
\text { Power in } \\
\text { Capture } \\
\text { Process } \\
{[\mathbf{k W}]}\end{array}$ & $\begin{array}{c}\mathbf{C O}_{2} \\
\text { Compre- } \\
\text { ssion } \\
{[\mathbf{k W}]}\end{array}$ & $\begin{array}{c}\mathbf{C O}_{2} \\
\text { Pump } \\
{[\mathbf{k W}]}\end{array}$ & $\begin{array}{c}\mathbf{H P} \\
\text { Compressor } \\
{[\mathbf{k W}]}\end{array}$ & $\begin{array}{c}\mathbf{S C O}_{2} \\
\text { Power } \\
{[\mathbf{k W}]}\end{array}$ & $\begin{array}{c}\text { Equival- } \\
\text { ent Work }\end{array}$ \\
\hline $\begin{array}{c}\text { Baseline } \\
\text { Case (BC) }\end{array}$ & 3.36 & N/A & 16691 & N/A & N/A & N/A & 0.974 \\
\hline $\begin{array}{c}\text { Proposed } \\
\text { Case (PC) }\end{array}$ & 2.65 & 1112 & 13465 & 1149 & 1077 & 983 & 0.820 \\
\hline
\end{tabular}

\section{Conclusion}

This study designed and evaluated a novel carbon capture and storage process configuration. The proposed configuration successfully reduced the energy expenditure of the carbon capture and storage 
process by enhancing heat integration. During the capture process, effective heat integration was achieved by incorporating three stripper modifications, namely: lean vapor compression, rich solvent splitting with vapor heat recovery and reboiler condensate heat recovery using an inter-heater stripper in a single flowsheet. The power required for the $\mathrm{CO}_{2}$ pressurization was reduced by assisting the multistage compressors with a heat pump system. The multistage compressors then increased then $\mathrm{CO}_{2}$ pressure to the level needed for liquefaction. The $\mathrm{CO}_{2}$ was then liquefied in the heat pump system and subsequently pumped to the required pressure. To improve the $\mathrm{CO}_{2}$ pressurization process, intercooling heat lost during multistage compression was recovered by integrating the heat pump-assisted pressurization scheme with a supercritical $\mathrm{CO}_{2}$ power cycle.

The performance of the proposed configuration was evaluated for a range of key operating parameters, i.e. split fraction (from 0.65 to 0.74 ), flash pressure (from 1.0 to 1.6 bar), stripper inter-heater location (from 2 to 18 stages) and flow rate (1000 to $3000 \mathrm{kmol} / \mathrm{hr}$ ), as well as $\mathrm{CO}_{2}$ liquefaction pressure (1710 and $5130 \mathrm{kPa}$ ), and the low pressure level of the supercritical $\mathrm{CO}_{2}$ cycle (from 70 to $100 \mathrm{bar}$ ). The parametric investigation results indicated the energy expenditure of the proposed configuration was minimized at the optimum values of the split fraction, flash pressure, stripper inter-heater location, stripper inter-heater flow rate, $\mathrm{CO}_{2}$ liquefaction pressure, and pressure ratio across supercritical $\mathrm{CO}_{2}$ cycle turbine. The performance of the proposed configuration at the optimized conditions was quantified in terms of equivalent work and it was concluded that $15.8 \%$ saving in equivalent work compared to the conventional carbon capture and storage process was achieved using the proposed process configuration. The proposed process configuration demonstrates technical superiority by significantly reducing the energy consumption of both the sequestration and pressurization processes. However, this study has focused on the potential energy savings without considering the capital costs of the proposed modifications, which should be taken into account to ascertain the economic viability of the proposed design.

\section{Acknowledgement}

This work was supported by the Development Program of the Korea Institute of Energy Research (KIER B9-2432) and by the "Local Demand Customized R\&D Support Project" (Project: Recycling of greenhouse and by-products gases utilizing low-grade waste heat from industrial complex) through the Korea Institute of S\&T Evaluation and Planning (KISTEP) funded by the Ministry of Science and ICT, Republic of Korea.

\section{References}


1. Energy Information Administration U. International Energy Outlook 2016. 2040.

2. Kılkış Ş, Krajačić G, Duić N, Montorsi L, Wang Q, Rosen MA. Research frontiers in sustainable development of energy, water and environment systems in a time of climate crisis. Energy Conv and Management 2019;199: 111938. https://doi.org/10.1016/j.enconman.2019.111938

3. Singh B, Strømman AH, Hertwich EG. Comparative life cycle environmental assessment of CCS technologies. Int J Greenh Gas Control 2011;5:911-21. doi:10.1016/j.ijggc.2011.03.012.

4. Alami AH, Hawili AA, Tawalbeh M, et al. Materials and logistics for carbon dioxide capture, storage and utilization. Science of The Total Environment 2020;717:137221. https://doi.org/10.1016/j.scitotenv.2020.137221

5. Mikulčić H, Skov IR, Dominković DF, Alwi SR, Manan ZA, Tan R, Duić N, Mohamad SN, Wang X. Flexible Carbon Capture and Utilization technologies in future energy systems and the utilization pathways of captured CO2. Renewable and Sustainable Energy Reviews. 2019 Oct 1;114:109338.

6. Cormos CC. Integrated assessment of IGCC power generation technology with carbon capture and storage (CCS). Energy 2012;42:434-45. doi:10.1016/j.energy.2012.03.025.

7. Leeson D, Mac Dowell N, Shah N, Petit C, Fennell PS. A Techno-economic analysis and systematic review of carbon capture and storage (CCS) applied to the iron and steel, cement, oil refining and pulp and paper industries, as well as other high purity sources. Int J Greenh Gas Control 2017;61:71-84. doi:10.1016/j.ijggc.2017.03.020.

8. Zhao R, Deng S, Zhao L, Liu Y, Tan Y. Energy-saving pathway exploration of CCS integrated with solar energy: literature research and comparative analysis. Energy Conversion and Management. 2015 Sep 15;102:66-80.

9. Barzagli F, Di Vaira M, Mani F, Peruzzini M. Improved solvent formulations for efficient $\mathrm{CO}_{2}$ absorption and low-temperature desorption. Chem Sus Chem 2012;5:1724-31. doi:10.1002/cssc.201200062.

10. Li K, Leigh W, Feron P, Yu H, Tade M. Systematic study of aqueous monoethanolamine (MEA)-based $\mathrm{CO}_{2}$ capture process: Techno-economic assessment of the MEA process and its improvements. Appl Energy 2016;165:648-59. doi:10.1016/j.apenergy.2015.12.109.

11. Rezazadeh F, Gale WF, Rochelle GT, Sachde D. Effectiveness of absorber intercooling for $\mathrm{CO}_{2}$ absorption from natural gas fired flue gases using monoethanolamine solvent. Int J Greenh Gas Control 2017;58:246-55. doi:10.1016/j.ijggc.2017.01.016.

12. Karimi M, Hillestad M, Svendsen HF. Positive and negative effects on energy consumption by interheating of stripper in $\mathrm{CO}_{2}$ capture plant. Energy Procedia 2012;23:15-22. doi:10.1016/j.egypro.2012.06.066. 
13. Cousins A, Cottrell A, Lawson A, Huang S, Feron PHM. Model verification and evaluation of the richsplit process modification at an Australian-based post combustion $\mathrm{CO}_{2}$ capture pilot plant. Greenh Gases Sci Technol 2012;2:329-45. doi:10.1002/ghg.1295.

14. Gao H, Zhou L, Liang Z, Idem RO, Fu K, Sema T, et al. Comparative studies of heat duty and total equivalent work of a new heat pump distillation with split flow process, conventional split flow process, and conventional baseline process for $\mathrm{CO}_{2}$ capture using monoethanolamine. Int J Greenh Gas Control 2014;24:87-97. doi:10.1016/J.IJGGC.2014.03.001.

15. Damartzis T, Papadopoulos AI, Seferlis P. Process flowsheet design optimization for various aminebased solvents in post-combustion $\mathrm{CO}_{2}$ capture plants. J Clean Prod 2016;111:204-16. doi:10.1016/J.JCLEPRO.2015.04.129.

16. Le Moullec Y, Neveux T, Al Azki A, Chikukwa A, Hoff KA. Process modifications for solvent-based post-combustion $\mathrm{CO}_{2}$ capture. Int $\mathrm{J}$ Greenh Gas Control 2014;31:96-112. doi:10.1016/J.IJGGC.2014.09.024.

17. Haider Sultan, Umair H. Bhatti, Jin Soo Cho. Minimization of Energy Consumption for Amine Based $\mathrm{CO}_{2}$ Capture Process by Process Modification. Journal of Energy Engineering, 2019;28(4):13-18. https://doi.org/10.5855/ENERGY.2019.28.4.013

18. Aminu MD, Nabavi SA, Rochelle CA, Manovic V. A review of developments in carbon dioxide storage. Appl Energy 2017;208:1389-1419. https://doi.org/10.1016/j.apenergy.2017.09.015.

19. Moore JJ, Lerche A, Delgado H, Allison T, and Pacheco J. Development of advanced centrifugal compressors and pumps for carbon capture and sequestration applications. In: Proceedings of the Fortieth Turbomachinery Symposium 2011.

20. Witkowski A, Rusin A, Majkut M, Rulik S, Stolecka K. Comprehensive analysis of pipeline transportation systems for $\mathrm{CO}_{2}$ sequestration. Thermodynamics and safety problems. Energy Conv and Management 2013;76:665-673. https://doi.org/10.1016/j.enconman.2013.07.087.

21. Moore JJ, Nored MG. Novel concepts for the compression of large volumes of carbon dioxide. In: Proceedings of ASME turbo expo 2008.

22. Alabdulkarem A, Hwang $\mathrm{Y}$, Radermacher R. Development of $\mathrm{CO}_{2}$ liquefaction cycles for $\mathrm{CO}_{2}$ sequestration. Appl Thermal Engineering 2012;33(34):144-156. https://doi.org/10.1016/j.applthermaleng.2011.09.027.

23. Romeo LM, Bolea I, Lara Y, Escosa JM. Optimization of intercooling compression in $\mathrm{CO}_{2}$ capture $\begin{array}{llll}\text { systems. } & \text { Appl 2009;29:1744-51. }\end{array}$ https://doi.org/10.1016/j.applthermaleng.2008.08.010. 
24. Kurtulus K, Coskun A, Ameen S, Yilmaz C, Bolatturk A. Thermoeconomic analysis of a $\mathrm{CO}_{2}$ compression system using waste heat into the regenerative organic Rankine Cycle. Energy Conv and Management 2018;168:588-598. https://doi.org/10.1016/j.enconman.2018.05.037.

25. Pei P, Barse K, Gil AJ, Nasah J. Waste heat recovery in $\mathrm{CO}_{2}$ compression, Int J Greenh Gas Control 2014;30:86-96. https://doi.org/10.1016/j.ijggc.2014.09.001.

26. Farajollahi H, Hossainpour S. Application of organic Rankine cycle in integration of thermal power plant with post-combustion $\mathrm{CO}_{2}$ capture and compression. Energy 2017;118:927-36. https://doi.org/10.1016/j.energy.2016.10.124.

27. Xu C, Xin T, Li X, Li S, Sun Y, Liu W, Yang Y. A thermodynamic analysis of a solar hybrid coalbased direct-fired supercritical carbon dioxide power cycle. Energy Conv and Management. 2019 Sep 15;196:77-91.

28. Ghorbani B, Mehrpooya M, Omid E. Hybrid solar liquefied natural gas, post combustion carbon dioxide capture and liquefaction. Energy Conv and Management 2020;207:112512. https://doi.org/10.1016/j.enconman.2020.112512

29. Muhammad H.A., Roh C., Cho J., Rehman Z., Sultan H., Baik Y.J., Lee B.J., A comprehensive thermodynamic performance assessment of $\mathrm{CO} 2$ liquefaction and pressurization system using a heat pump for Carbon Capture and Storage (CCS) process. Energy Conversion and Management 2020; 206:112489.

30. Aliyon K, Hajinezhad A, Mehrpooya M. Energy assessment of coal-fired steam power plant, carbon capture, and carbon liquefaction process chain as a whole. Energy Conversion and Management. 2019 Nov 1;199:111994.

31. Jin $\mathrm{H}$, Liu P, Li Z. Energy-efficient process intensification for post-combustion $\mathrm{CO}_{2}$ capture: A modeling approach. Energy 2018;158:471-83. doi:10.1016/J.ENERGY.2018.06.045.

32. Sarkar J. Review and future trends of supercritical $\mathrm{CO}_{2}$ Rankine cycle for low-grade heat conversion. Renewable and Sustainable Energy Reviews 2015;48:434-451. https://doi.org/10.1016/j.rser.2015.04.039.

33. Liu Y, Zhang L, Watanasiri S. Representing Vapor-Liquid Equilibrium for an Aqueous $\mathrm{MEA}-\mathrm{CO}_{2}$ System Using the Electrolyte Non Random-Two-Liquid Model. Ind Eng Chem 1999;38(5):2080-2090. doi:10.1021/IE980600V.

34. Le Moullec Y, Kanniche M. Screening of flowsheet modifications for an efficient monoethanolamine (MEA) based post-combustion $\mathrm{CO}_{2}$ capture. International journal of greenhouse gas control 2011;5(4):727-740.

35. Takenouchi S, Kennedy GC. The binary system $\mathrm{H}_{2} \mathrm{O}-\mathrm{CO}_{2}$ at high temperatures and pressures. American Journal of Science 1964;262:1055-74. doi:10.2475/ajs.262.9.1055. 
659 36. Wang YW, Xu S, Otto FD, Mather AE. Solubility of $\mathrm{N}_{2} \mathrm{O}$ in alkanolamines and in mixed solvents. The 660 Chem Engg Journal 1992;48(1):31-40. doi.org/10.1016/0300-9467(92)85004-S.

661 37. Austgen DM, Rochelle GT, Peng X, Chen CC. Model of vapor-liquid equilibria for aqueous acid gas662 alkanolamine systems using the electrolyte-NRTL equation. Ind Eng Chem Res 1989;28:1060-73. 663 doi:10.1021/ie00091a028.

664 38. Bravo LJ. Mass Transfer in Gauze Packings. Hydrocarb Process 1985;64:91-5.

665 39. Muhammad HA, Lee B, Lee G, Cho J, Baik YJ. Investigation of leakage reinjection system for 666 supercritical $\mathrm{CO}_{2}$ power cycle using heat pump. Renewable Energy 2019;144:97-106. 667 https://doi.org/10.1016/j.renene.2018.10.059.

668 40. Campos JC, Moura D, Costa AP, Yokoyama L, Araujo FV, Cammarota MC, Cardillo L. Evaluation of $669 \mathrm{pH}$, alkalinity and temperature during air stripping process for ammonia removal from landfill leachate. 670 Journal of Environmental Science and Health, Part A 2013;48(9):1105-13.

671 41. Zhao Y, Wang B, Chi J, Xiao Y. Parametric study of a direct-fired supercritical carbon dioxide power 672 cycle coupled to coal gasification process. Energy Conv and Management 2018;156:733-745. 673 https://doi.org/10.1016/j.enconman.2017.11.044

674

675 